\title{
\#USGS
}

Prepared in cooperation with the Bureau of Land Management

Evaluation of Streamflow Extent and Hydraulic Characteristics of a Restored Channel at Soldier Meadows, Black Rock Desert-High Rock Canyon Emigrant Trails National Conservation Area, Nevada

Scientific Investigations Report 2020-5143

U.S. Department of the Interior

U.S. Geological Survey 
Cover: Riparian vegetation along stream channel at site USGS-412057119125501—SMDD natural channel. Photograph by Christopher Morris, U.S. Geological Survey, August 14, 2019. 


\section{Evaluation of Streamflow Extent and Hydraulic Characteristics of a Restored Channel at Soldier Meadows, Black Rock Desert-High Rock Canyon Emigrant Trails National Conservation Area, Nevada}

By Christopher M. Morris

Prepared in cooperation with the Bureau of Land Management

Scientific Investigations Report 2020-5143 


\section{U.S. Geological Survey, Reston, Virginia: 2021}

For more information on the USGS - the Federal source for science about the Earth, its natural and living resources, natural hazards, and the environment—visit https://www.usgs.gov or call 1-888-ASK-USGS.

For an overview of USGS information products, including maps, imagery, and publications, visit https://store.usgs.gov/.

Any use of trade, firm, or product names is for descriptive purposes only and does not imply endorsement by the U.S. Government.

Although this information product, for the most part, is in the public domain, it also may contain copyrighted materials as noted in the text. Permission to reproduce copyrighted items must be secured from the copyright owner.

Suggested citation:

Morris, C.M., 2021, Evaluation of streamflow extent and hydraulic characteristics of a restored channel at Soldier Meadows, Black Rock Desert-High Rock Canyon Emigrant Trails National Conservation Area, Nevada: U.S. Geological Survey Scientific Investigations Report 2020-5143, 22 p., https://doi.org/10.3133/sir20205143.

Associated data for this publication:

Morris, C.M., 2021, Geospatial data and surface-water model archive for evaluation of streamflow extent and hydraulic characteristics of a restored channel at Soldier Meadows, Black Rock Desert-High Rock Canyon Emigrant Trails National Conservation Area, Nevada: U.S. Geological Survey data release, https://doi.org/10.5066/P900GII7.

ISSN 2328-0328 (online) 


\section{Contents}

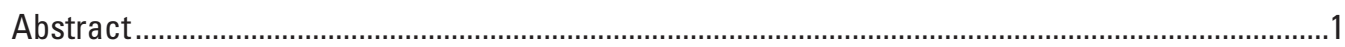

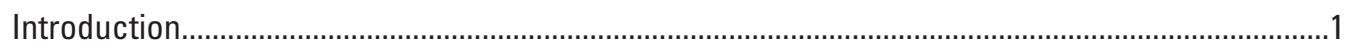

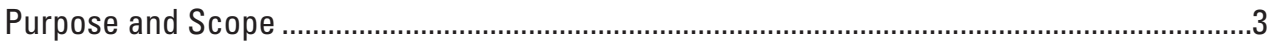

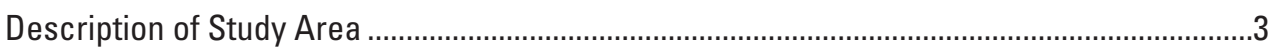

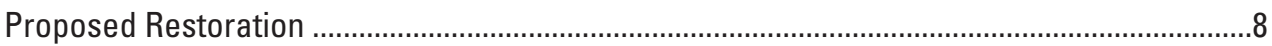

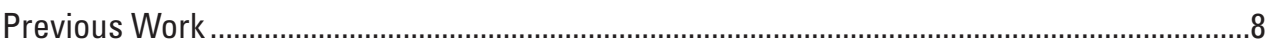

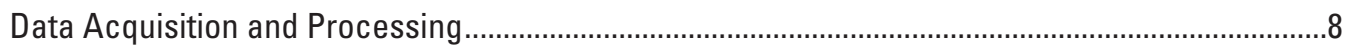

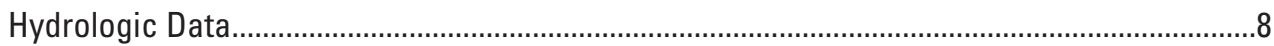

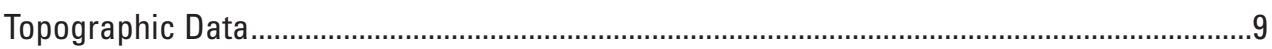

Evaluation of Streamflow Extent and Hydraulic Characteristics....................................................11

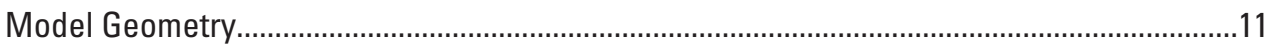

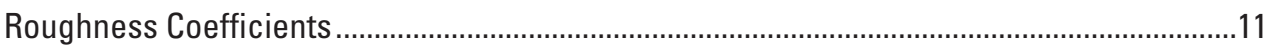

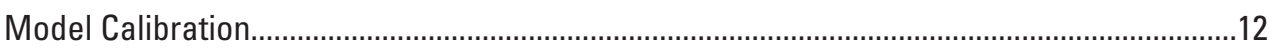

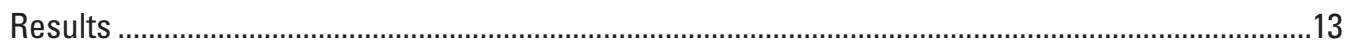

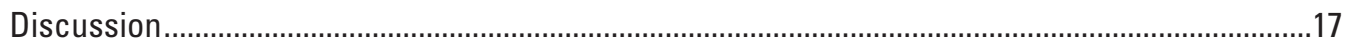

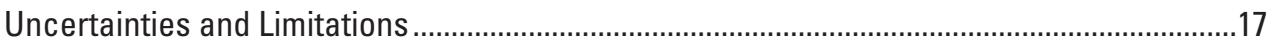

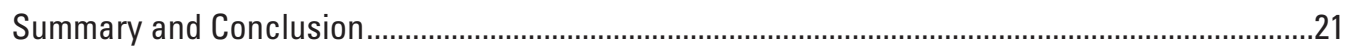

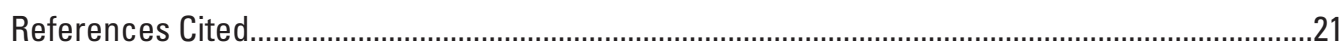

\section{Figures}

1. Map showing location of Soldier Meadows, Black Rock Desert-High Rock Canyon Emigrant Trails National Conservation Area, Nevada .........................................2

2. Map showing study area, Soldier Meadows, Black Rock Desert-High Rock Canyon Emigrant Trails National Conservation Area, Nevada ...........................................4

3. Photographs showing examples of stream channels and irrigation ditches, Soldier Meadows, Black Rock Desert-High Rock Canyon Emigrant Trails National Conservation Area, Nevada...

4. Flow schematic for area 4, Soldier Meadows, Black Rock Desert-High Rock Canyon Emigrant Trails National Conservation Area, Nevada .........................................6

5. Photographs of the dewatered natural stream channel, Soldier Meadows, Black Rock Desert-High Rock Canyon Emigrant Trails National Conservation Area, Nevada

6. Map showing model area, Soldier Meadows, Black Rock Desert-High Rock Canyon Emigrant Trails National Conservation Area, Nevada

7. Graph showing simulated versus surveyed water surface elevations, Soldier Meadows, Black Rock Desert-High Rock Canyon Emigrant Trails National Conservation Area, Nevada

8. Map showing simulated streamflow extents, Soldier Meadows, Black Rock Desert-High Rock Canyon Emigrant Trails National Conservation Area, Nevada ..........14

9. Map showing simulated total streamflow channel depths, Soldier Meadows, Black Rock Desert-High Rock Canyon Emigrant Trails National Conservation Area, Nevada.

10. Map showing simulated streamflow velocity, Soldier Meadows, Black Rock Desert-High Rock Canyon Emigrant Trails National Conservation Area, Nevada 
11. Map showing color infrared aerial photograph of study area in 1981, Soldier Meadows, Black Rock Desert-High Rock Canyon Emigrant Trails National Conservation Area, Nevada

12. Map showing study area in 1994, Soldier Meadows, Black Rock Desert-High Rock Canyon Emigrant Trails National Conservation Area, Nevada 19

13. Map showing study area in 2006, Soldier Meadows, Black Rock Desert-High Rock Canyon Emigrant Trails National Conservation Area, Nevada

\section{Tables}

1. Streamflow measurement and computed roughness coefficients

2. Estimated streamflow and increase in channel depth of natural channel with irrigation ditches filled in.

\section{Conversion Factors}

U.S. customary units to International System of Units

\begin{tabular}{|c|c|c|}
\hline Multiply & By & To obtain \\
\hline \multicolumn{3}{|c|}{ Length } \\
\hline inch (in.) & 2.54 & centimeter $(\mathrm{cm})$ \\
\hline inch (in.) & 25.4 & millimeter $(\mathrm{mm})$ \\
\hline foot $(\mathrm{ft})$ & 0.3048 & meter $(\mathrm{m})$ \\
\hline \multicolumn{3}{|c|}{ Area } \\
\hline square foot $\left(\mathrm{ft}^{2}\right)$ & 0.09290 & square meter $\left(\mathrm{m}^{2}\right)$ \\
\hline \multicolumn{3}{|c|}{ Volume } \\
\hline cubic foot $\left(\mathrm{ft}^{3}\right)$ & 0.02832 & cubic meter $\left(\mathrm{m}^{3}\right)$ \\
\hline \multicolumn{3}{|c|}{ Flow rate } \\
\hline foot per second (ft/s) & 0.3048 & meter per second $(\mathrm{m} / \mathrm{s})$ \\
\hline cubic foot per second $(\mathrm{ft} 3 / \mathrm{s})$ & 0.02832 & cubic meter per second $\left(\mathrm{m}^{3} / \mathrm{s}\right)$ \\
\hline
\end{tabular}

\section{Datum}

Vertical coordinate information is referenced to the North American Vertical Datum of 1988 (NAVD 88).

Horizontal coordinate information is referenced to the North American Datum of 1983 (NAD 83).

Elevation, as used in this report, refers to distance above the vertical datum. 


\title{
Abbreviations
}

\author{
ACEC Area of Critical Environmental Concern \\ BLM Bureau of Land Management \\ DTM digital terrain model \\ GNSS Global Navigation Satellite System \\ HEC-RAS Hydrologic Engineering Center's River Analysis System \\ lidar light imaging, detection, and ranging \\ NCA National Conservation Area \\ NDOW Nevada Department of Wildlife \\ OPUS-S Online Positioning User Service-Static \\ RMSE root mean square error \\ RTK real-time kinematic \\ SMDD Soldier Meadows Desert Dace \\ TIN triangulated irregular network \\ USFWS U.S. Fish and Wildlife Service \\ USGS U.S. Geological Survey
}





\title{
Evaluation of Streamflow Extent and Hydraulic Characteristics of a Restored Channel at Soldier Meadows, Black Rock Desert-High Rock Canyon Emigrant Trails National Conservation Area, Nevada
}

\author{
By Christopher M. Morris
}

\begin{abstract}
The Soldier Meadows spring complex provides habitat for the desert dace, an endemic and threatened fish. The spring complex has been altered with the construction of irrigation ditches that remove water from natural stream channels. Irrigation ditches generally provide lower quality habitat for the desert dace. Land and wildlife management agencies are interested in increasing habitat extent and quality by filling in irrigation ditches and restoring streamflow to natural channels. The U.S. Geological Survey measured streamflow, surveyed topography, and combined light detection and ranging data to create a two-dimensional hydraulic model of the study area to understand how restoration would change streamflow extents and hydraulic characteristics. Streamflow measurements indicate that, except for a section of one irrigation ditch at the upstream end of the study area, the total volume of streamflow diverted into the irrigation ditches in the study area was minimal. Hydraulic modeling indicates filling in the irrigation ditch at the upper end of the study area would return streamflow to the natural channel, resulting in an increase in natural channel surface water extent, and a reduction of irrigation ditch surface water flow. The result would be a more heterogenous natural stream channel, ranging from shallow and slow to narrow and fast.
\end{abstract}

\section{Introduction}

The Soldier Meadows spring complex is in northwestern Nevada in the Black Rock Desert-High Rock Canyon Emigrant Trails National Conservation Area (fig. 1). The springs, as well as associated wetland and riparian areas, provide important habitat for many species in otherwise dry desert shrublands, including the endemic desert dace (Eremichthys acros), a federally listed threatened fish species (U.S. Fish and Wildlife Service, 1997). Desert dace inhabit several different aquatic habitat types, including spring pools, flowing channels, and emergent wetlands. Sections of the spring complex have been designated as the Soldier Meadows Area of Critical Environment Concern (ACEC) by the Bureau of Land Management (BLM) in order to protect desert dace and other sensitive species habitat (fig. 1).

Since Euro-American settlement in the 19th century, the spring complex has experienced many alterations. Most importantly for this study, several irrigation ditches have been dug to irrigate fields or provide livestock water; some ditches may date as early as the 1860s (U.S. Fish and Wildlife Service, 1997). Nyquist (1963) gives several examples of dramatic channel alternations for irrigation purposes and their effects on desert dace, including complete dewatering of a channel and deaths of large numbers of desert dace in the 1960s. In general, irrigation ditches have dewatered natural channels, resulting in generally lower quality habitat and a reduction of total desert dace habitat (Vinyard, 1996). In recent years, recreational use by the public has increased, including direct channel manipulation by creating rock dams to deepen pools for bathing. Although this use is mostly focused upstream of dace habitat in hot springs, water quality effects from increased turbidity, the use of soap and shampoo by bathers, and increased human waste could have affects downstream (U.S. Fish and Wildlife Service, 1997). Finally, non-native, invasive green sunfish and goldfish have been illegally stocked in the downstream Mud Meadow Reservoir and can prey on dace; this has necessitated the construction of a fish barrier at the downstream end of the study area (Rissler and Scoppettone, 2004). 
$119^{\circ} 15^{\prime}$

$119^{\circ} 12^{\prime}$

$119^{\circ} 9^{\prime}$

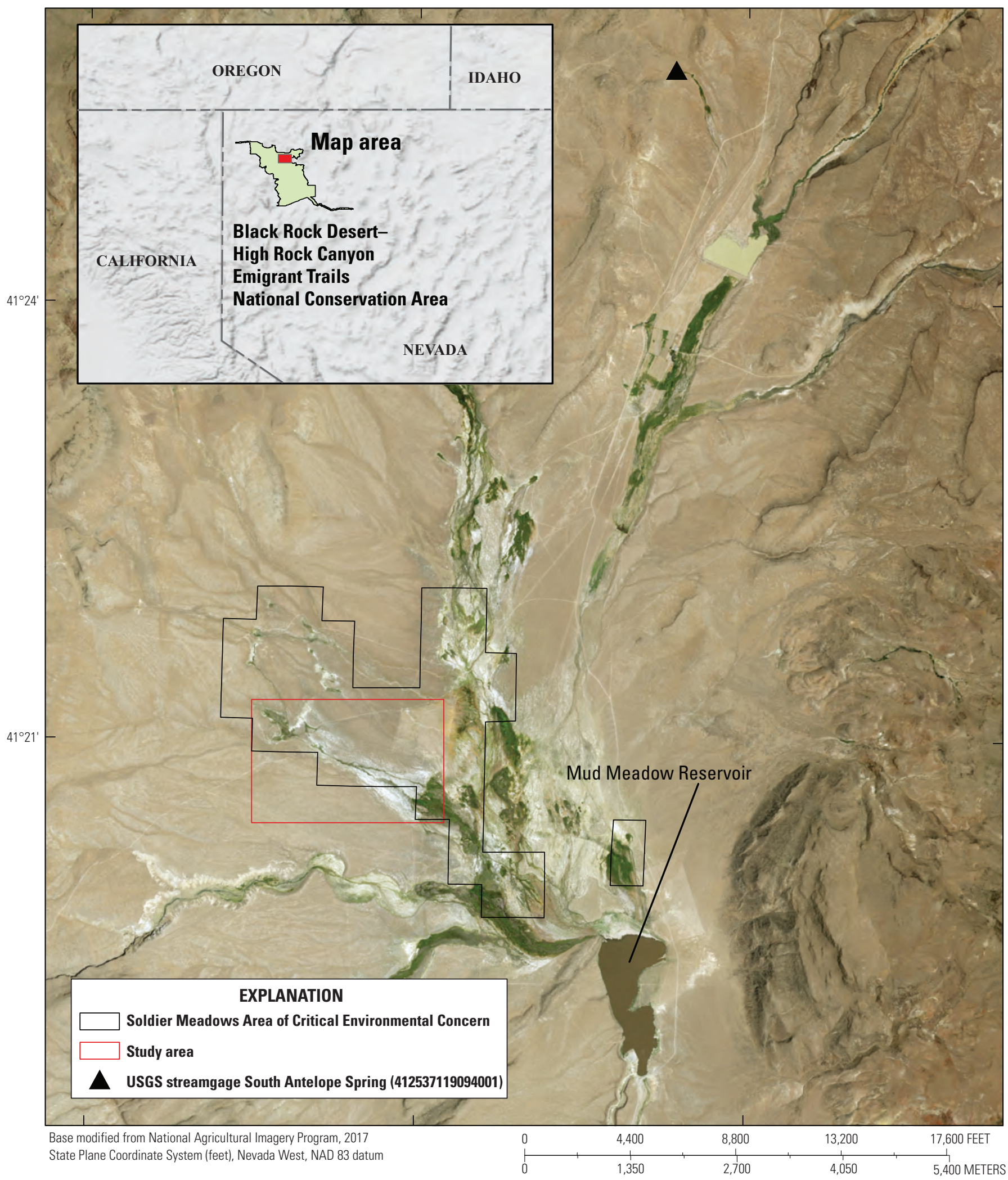

Figure 1. Location of Soldier Meadows, Black Rock Desert-High Rock Canyon Emigrant Trails National Conservation Area, Nevada. 
Desert dace use a wide variety of habitats based on seasonality and their life stage. During winter, desert dace move upstream to warmer springheads, and in summer they move farther downstream where water is cooler. Desert dace have been found in spring pools 50 feet $(\mathrm{ft})$ wide and $11 \mathrm{ft}$ deep, while larvae have been observed in dense emergent wetlands less than $0.16 \mathrm{ft}$ deep. Monitoring efforts by the Nevada Department of Wildlife (NDOW) classified desert dace habitat as either springhead, irrigation ditch, flowing channel, wet meadow, or pool (Bauman, 2019). Individual springs, stream channels, and irrigation ditches have not been named, complicating comparison between studies. For this study, channels and irrigation ditches have been named Soldier Meadows Desert Dace (SMDD) along with channel type, with increasing numbers in the downstream direction.

Improving habitat and increasing desert dace populations are a joint goal of the BLM, NDOW, and U.S. Fish and Wildlife Service (USFWS). One strategy to help the recovery of desert dace is to restore streamflow to sections of natural channels where streamflow has been reduced or eliminated by diversions into irrigation ditches. The restoration of desert dace to a dewatered natural stream channels is one of the criteria listed in the species' recovery plan (U.S. Fish and Wildlife Service, 1997). For the desert dace, this restoration action would change the spatial extent of the different habitat types. However, restoration has the possibility of sending streamflow to undesired locations such as road crossings or other irrigation channels.

\section{Purpose and Scope}

The purpose of this report is to aid the BLM and other agencies in (1) understanding the current distribution of streamflow within the study area, in particular, streamflow diverted into irrigation ditches and (2) determining how surface water extents will change under the proposed restoration. In order to help answer these questions, the study includes measurement of streamflow in natural channels and irrigation ditches as well as evaluation of surface water extent and hydraulic characteristics using a 2-dimensional hydraulic model of the proposed restoration area.

\section{Description of Study Area}

The spring complex is located at the north end of the Black Rock Desert-High Rock Canyon Emigrant Trails National Conservation Area (NCA). The Soldier Meadows ACEC is only a small part of the much larger NCA but covers almost the entire study area. The complex consists of dozens of springs and seeps, some isolated, others clustered in groups. In some places, spring flow merges to form stream channels that flow downslope to the valley bottom and eventually to
Mud Meadow Reservoir. The study area is a small section of the spring complex (fig. 2) that contains the largest contiguous desert dace habitat and is a subsection of area 4 as defined by Vinyard (1996).

Stream channels, irrigation ditches, and emergent wetlands occur within the study area. Many locations with water have very dense emergent wetland vegetation dominated by hardstem bulrush (Schoenoplectus acutus) and other wetland plants. Heavy thatch from the bulrush means that the true spatial extent of surface water is difficult to discern. Stream channels tend to be more open, especially in areas with gravel or cobble substrate, however, in many locations, vegetation forms a closed canopy over the stream channel water surface (fig. 3). Hubbs and Miller (1948) as well as Nyquist (1963) both provide early descriptions of vegetation and channel shape in the spring complex that are very similar to current conditions.

Streamflow in the study area is complex, and gaining a better understanding of streamflow distribution is part of this study. In August 2019, streamflow discharged from wetland 1 in irrigation ditch 1 and flowed east (figs. 2 and 4 in blue). The natural stream channel (fig. 4 in red) that goes southeast from wetland 1 was completely dewatered by diversion into irrigation ditch 1 . After about $575 \mathrm{ft}$, near the intersection with wetland 2, almost all of the streamflow discharged from irrigation ditch 1 and flowed southeast into an incised channel that returns flow to the natural channel. Irrigation ditch 1 continued east from the incised channel but was dry within several hundred feet. The streamflow in the incised channel flowed back to the natural channel just downstream of the first road crossing. The natural channel then flowed to the southeast for about 2,000 ft, where irrigation ditch 2 then diverted a small amount of streamflow to the east. The remaining streamflow in the natural channel flowed downstream for about 2,800 ft to another road and a fish barrier/culvert, where irrigation ditches 3 and 4 diverted a small amount of streamflow to the north and south. Finally, the remaining streamflow in the natural channel entered a wetland that is beyond the extent of the current restoration and study area.

During the field survey within the dewatered natural channel, several features were found illustrating the consequences of the dewatering. Parts of the channel had dry, friable root masses (fig. 5). The remaining wetland plants were stunted, and the channel was being colonized by rabbitbrush (Chrysothamnus sp.), cheatgrass (Bromus tectorum), and sagebrush (Artemisia sp.), indicating a transition from wetland to phreatophytic-upland vegetation that has been observed in other Great Basin springs as a result of drying (Patten and others, 2008). The last occurrence of streamflow in the dewatered channel is unknown; however, satellite images from 1981 and 1994 both show much denser vegetation than what is currently present, perhaps indicating some streamflow may have occurred in the dewatered channel during those periods. 


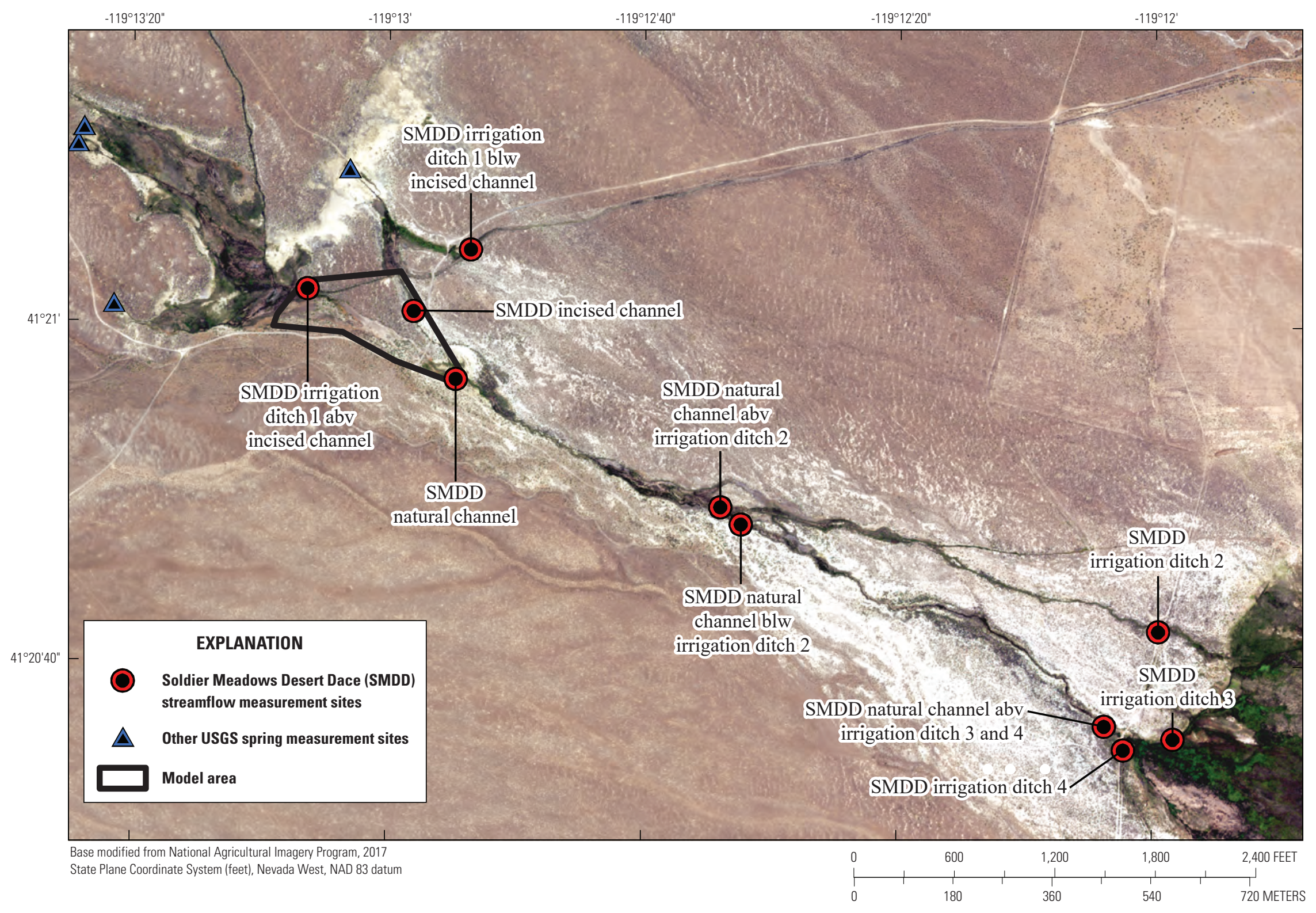

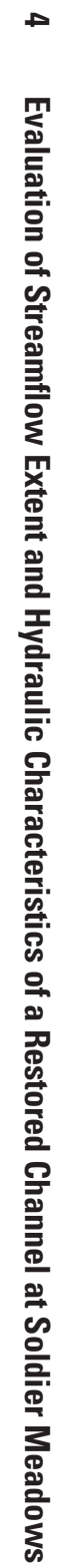

Figure 2. Study area, Soldier Meadows, Black Rock Desert-High Rock Canyon Emigrant Trails National Conservation Area, Nevada. 
A

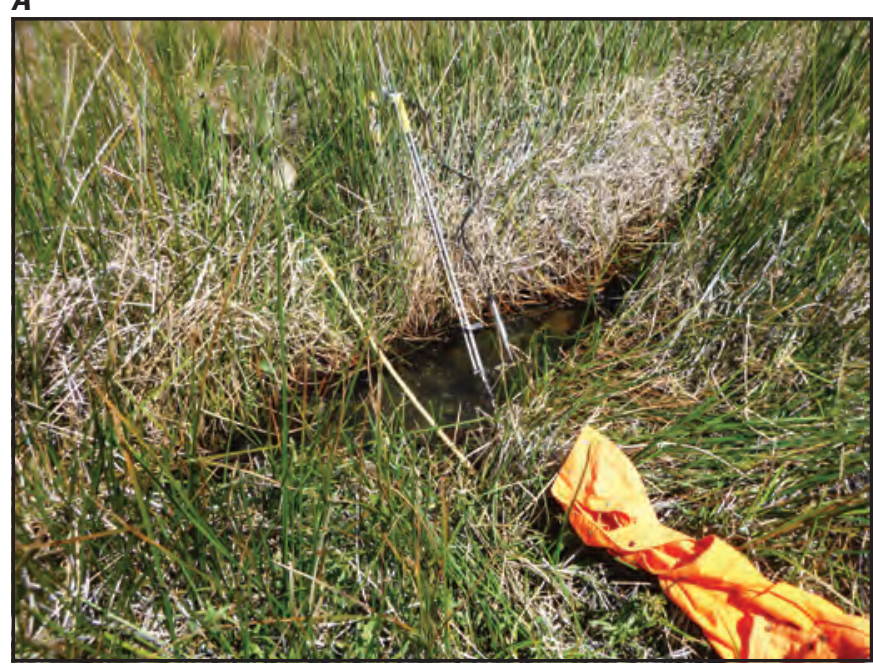

$c$

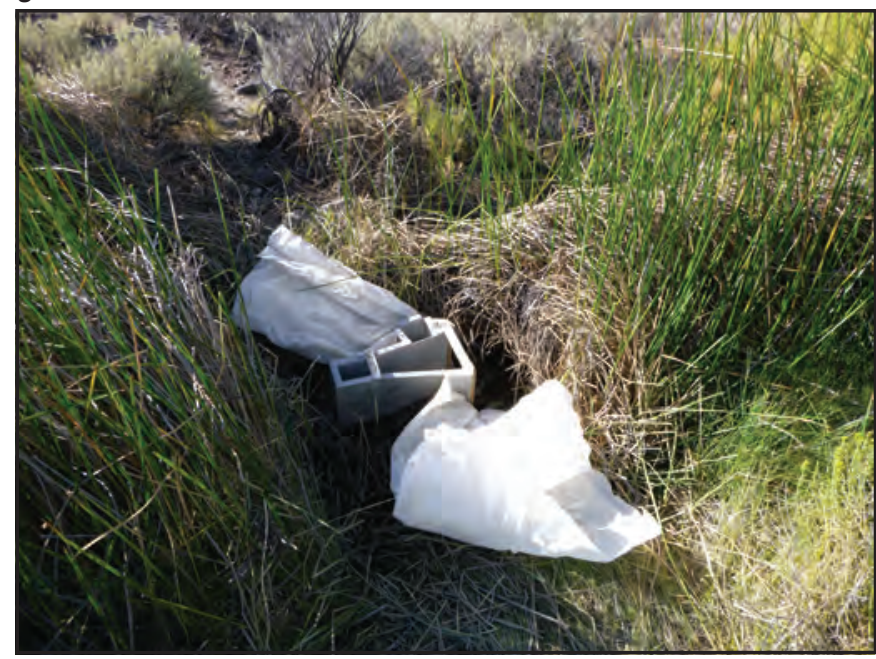

B

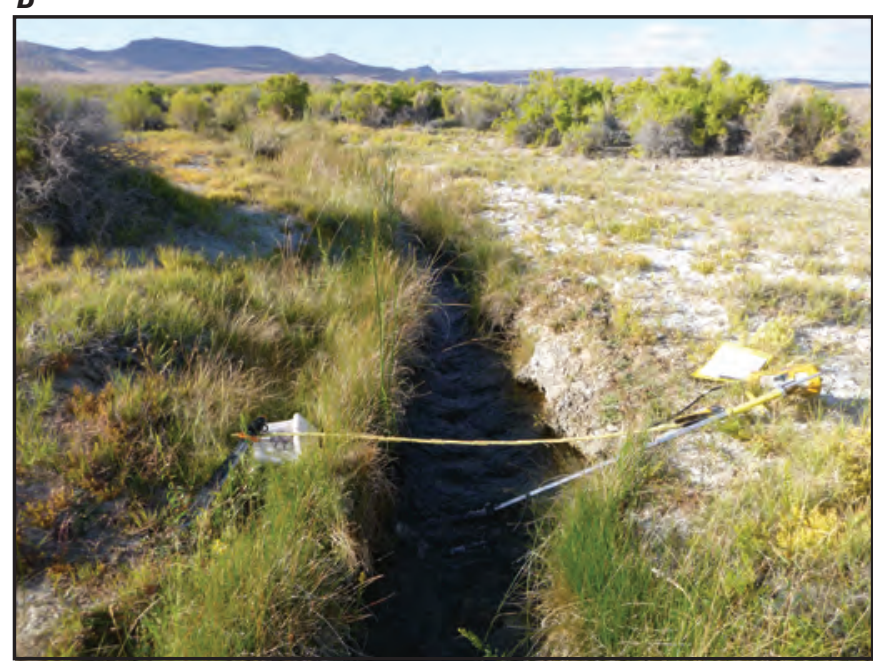

D

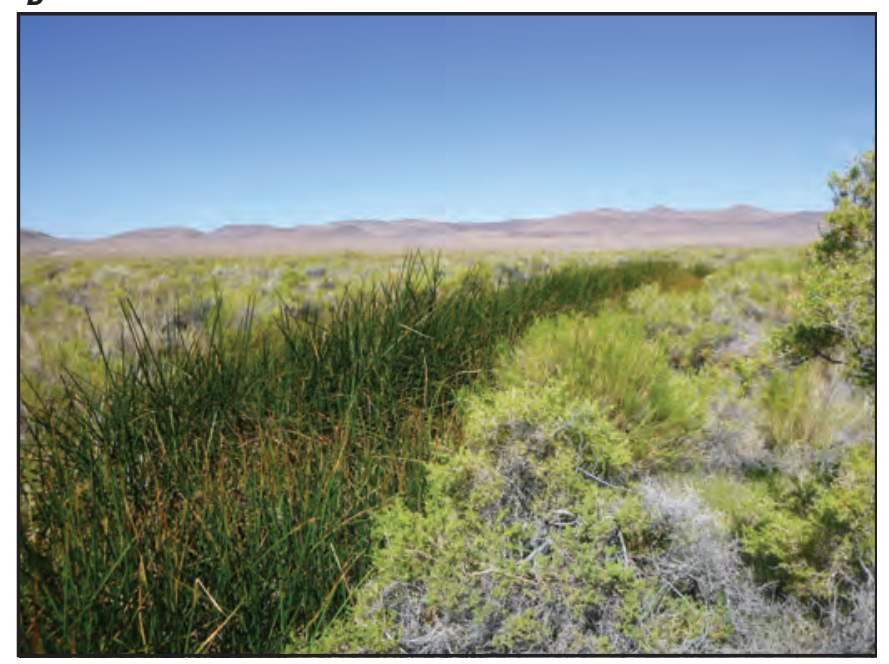

Figure 3. Examples of stream channels and irrigation ditches, Soldier Meadows, Black Rock Desert-High Rock Canyon Emigrant Trails National Conservation Area, Nevada. 


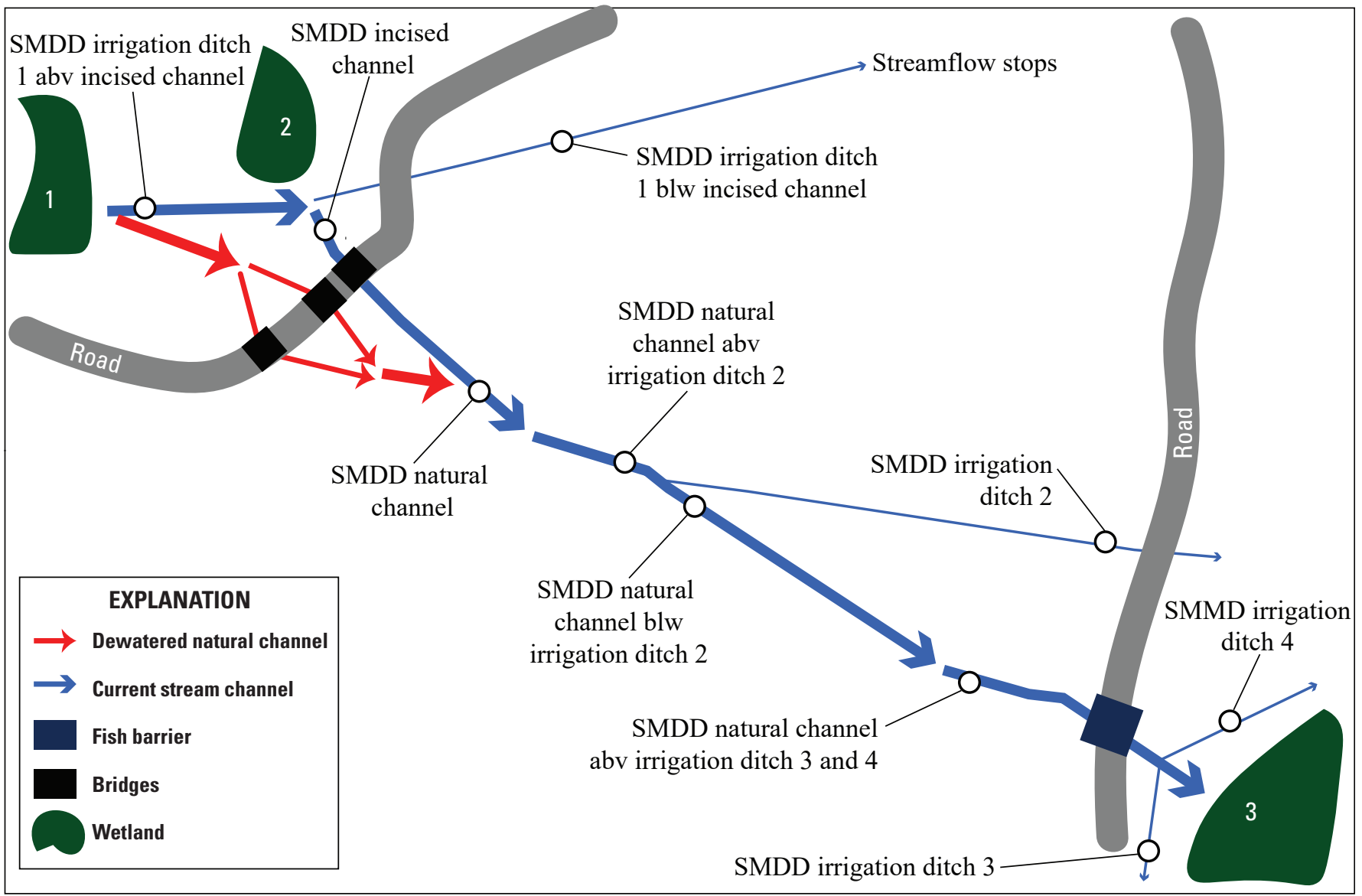

Figure 4. Flow schematic for area 4, Soldier Meadows, Black Rock Desert-High Rock Canyon Emigrant Trails National Conservation Area, Nevada. 
A

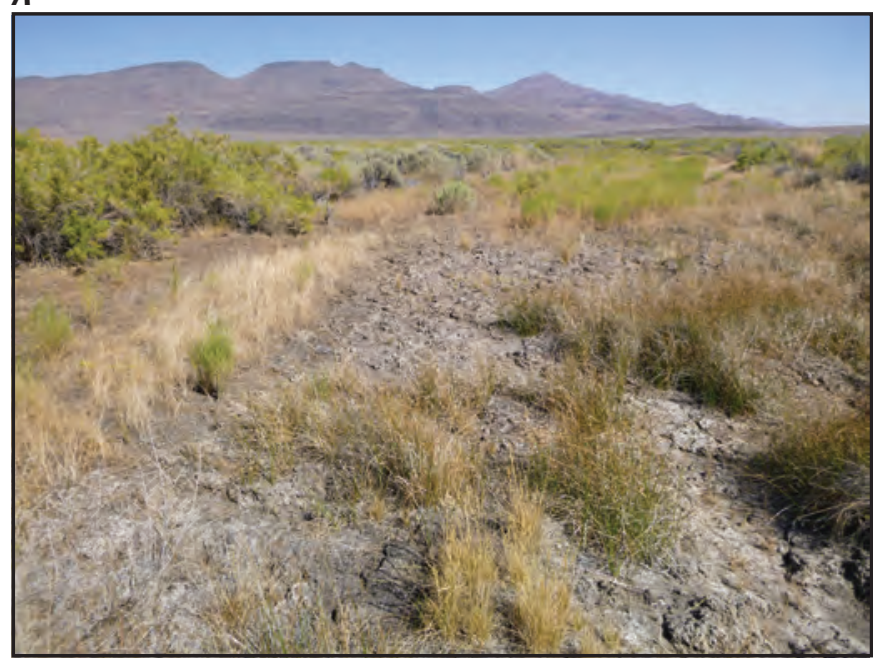

$c$

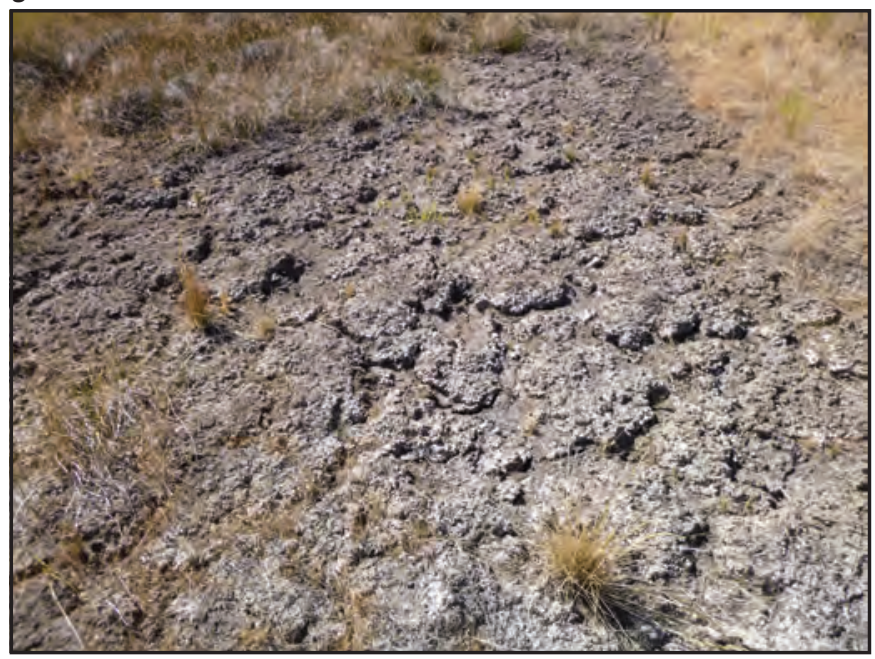

$\boldsymbol{B}$

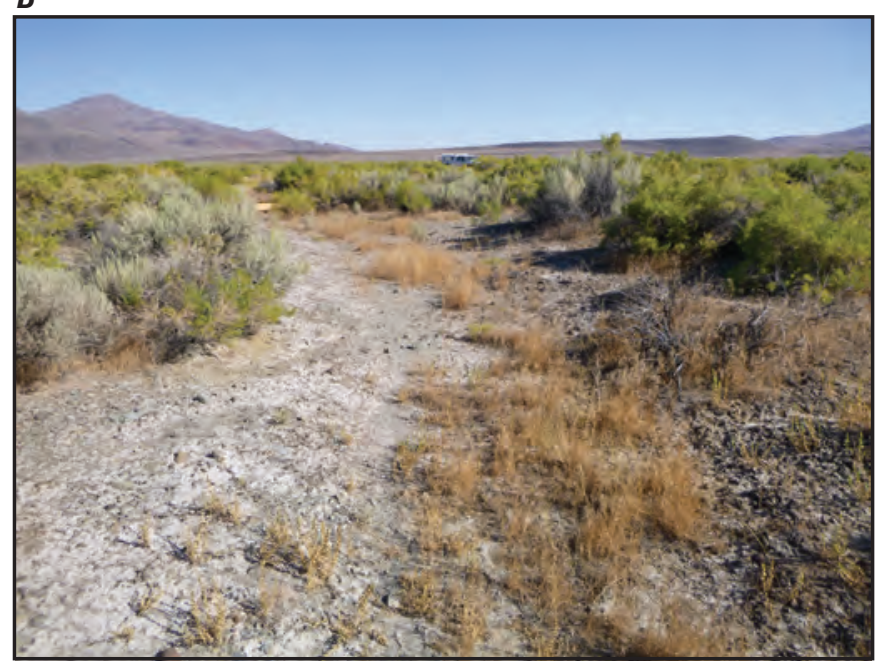

D

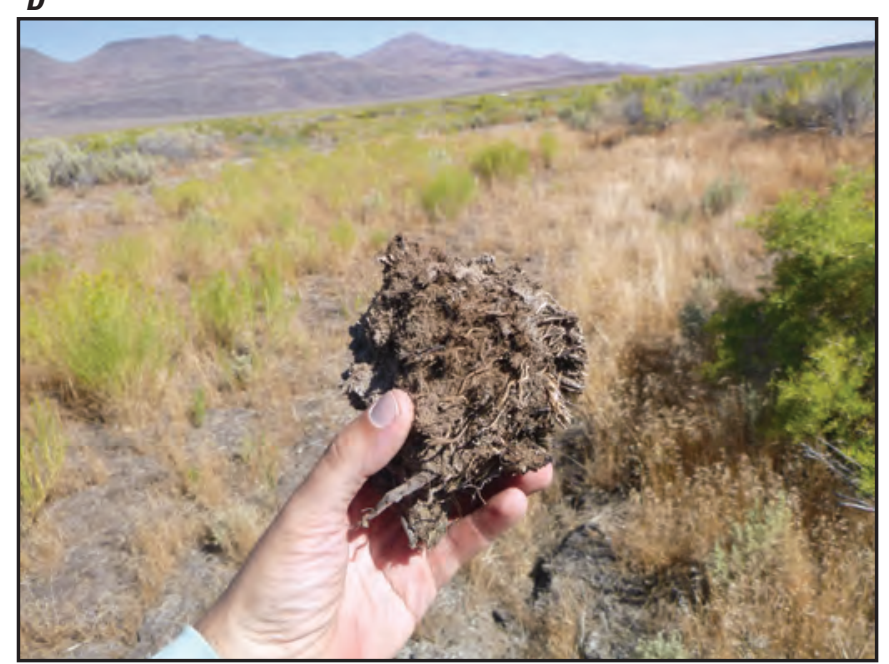

Figure 5. Dewatered natural stream channel, Soldier Meadows, Black Rock Desert-High Rock Canyon Emigrant Trails National Conservation Area, Nevada. 


\section{Proposed Restoration}

The BLM is proposing to restore streamflow to the natural channel through a sequence of actions, from upstream to downstream areas. At the upstream end of the study area, irrigation ditch 1 would be filled for about $200 \mathrm{ft}$ with the goal of returning streamflow to the currently dewatered natural channel. The incised channel would be completely filled for its entire length from irrigation ditch 1 to the natural channel. Sediment that has filled in under two bridges would be removed to allow streamflow restored to the previously dewatered natural channel to flow through. From the natural channel downstream for about $65 \mathrm{ft}$, irrigation ditch 2 would be filled in. Finally, at the downstream end of the study area, the first $200 \mathrm{ft}$ of irrigation ditches 3 and 4 downstream from the natural channel would be filled in.

\section{Previous Work}

Desert dace have been studied by several researchers, primarily focusing on fish biology and ecology, with less emphasis on the hydrology and geomorphology of the Soldier Meadows spring complex (U.S. Fish and Wildlife Service, 1997). Measurements in 1987 (Vinyard, 1988) found most of the streamflow continued southeast in the natural channel past irrigation ditch 1 (whether through the incised channel or the currently dewatered natural channel isn't clear), with an estimated mean streamflow of 2.09 cubic feet per second $(\mathrm{ft} 3 / \mathrm{s})$. Farther downstream, only about $0.53 \mathrm{ft} 3 / \mathrm{s}$ continued past irrigation ditch 2 in the natural channel. In 1989, irrigation ditch 1 was re-dredged and nearly all the streamflow was diverted from the natural channel into the ditch, with no streamflow reaching the downstream wetland 3 by the natural channel. Vinyard (1996) found fish catches dropped about 70 percent from May 1988 (pre-dredging) to October 1989 (post-dredging) in the study area. Even 6 years after the dredging, 81 percent of the total streamflow was still diverted into irrigation ditch 1 , and fish catches were still about 50 percent less than before dredging. Fish trapping occurred again in 2002-03 and from 2014 to present using different sampling methods (Rissler and Scoppettone, 2004; Bauman, 2019). Trapping in the study area found a 333-percent increase in fish catches from 2002-2003 to 2014, but then a 52-percent decrease from 2014 to 2019 (Bauman, 2019).

The U.S. Geological Survey (USGS) made discrete streamflow measurements in 1980 at a number of sites and in 2013 at one site in the spring complex. Those measurements represent discharge at springheads and not the stream channels and irrigation ditches that are the main focus of this study. Continuous streamflow data for South Antelope Spring (USGS gage 412537119094001), just north of the spring complex, show no variation in streamflow over the period of operation, from November 2012 to June 2014 (U.S. Geological Survey, 2019a). This gage, however, was located directly at a springhead where the effect of evapotranspiration on stream discharge would be limited as a result of limited vegetation. Farther downstream, evapotranspiration from vegetation could result in more variable streamflow. The collection of additional USGS discrete streamflow measurements began in August 2019 at several sites in the spring complex; however, only limited data were available for use in this report.

\section{Data Acquisition and Processing}

Field data were collected from August 12 to 16, 2019, by USGS personnel. A total of 11 streamflow measurements were made on selected stream channels and irrigation ditches. Additionally, Global Navigation Satellite System (GNSS) surveys were made on select topographic locations and features such as bridges and a culvert.

\section{Hydrologic Data}

In order to provide streamflow data for the hydraulic model and quantify the amount of streamflow in irrigation ditches, 11 streamflow measurements were made at 10 locations in the study area (table 1). Measurements were made with either an acoustic Doppler velocimeter or portable Parshall flumes (3-inch or 1-inch) following the procedures detailed in Turnipseed and Sauer (2010) and are published in the USGS National Water Information System (U.S. Geological Survey, 2019b).

Streamflow is diverted from the main channel to irrigation ditch 1 below the incised channel and also from the main channel to irrigation ditches 2-4. Because of the small quantity of streamflow diverted to the irrigation ditches and the natural stream channel shape (mostly deep, narrow, and several tenths of feet below the surrounding land surface), the increase in habitat extent likely would be minimal if the irrigation ditches were to be filled in. To quantify changes to channel depth, streamflow measurements were adjusted to account for the increase in discharge that would result if the irrigation ditches were filled. The measured streamflow $\left(Q_{m}\right)$ at natural channel locations can be described as:

$$
Q_{m}=A_{m} V_{m}=D_{m} W_{m} V_{m}
$$

where

$$
\begin{array}{ll}
A_{m} & \text { is the measured area, } \\
V_{m} & \text { is the measured mean velocity, } \\
D_{m} & \text { is the measured mean depth, and } \\
W_{m} & \text { is the measured channel width. }
\end{array}
$$

The estimated streamflow $\left(Q_{e}\right)$ at the same natural channel location with the irrigation ditches filled in is the measured streamflow of the irrigation ditches $\left(Q_{I D}\right)$ added to the measured streamflow of the channel location $\left(Q_{m}\right)$ :

$$
Q_{e}=Q_{m}+Q_{I D}
$$


Table 1. Streamflow measurement and computed roughness coefficients.

[mm/dd/yyyy, month/day/year; SMDD, Soldier Meadows Desert Dace; abv, above; blw, below; NA, not available]

\begin{tabular}{|c|c|c|c|c|c|c|}
\hline Site name & Site number & $\begin{array}{l}\text { Measured streamflow } \\
\text { (cubic feet per } \\
\text { second) }\end{array}$ & $\begin{array}{c}\text { Date } \\
\text { (mm/dd/ } \\
\text { yyyy) }\end{array}$ & Method & Quality & $\begin{array}{l}\text { Computed } \\
\text { roughness } \\
\text { coefficient }\end{array}$ \\
\hline $\begin{array}{l}\text { SMDD irrigation ditch } 1 \\
\text { abv incised channel }\end{array}$ & 412102119130601 & 1.94 & $08 / 13 / 2019$ & Acoustic doppler velocimeter & Poor & 0.091 \\
\hline $\begin{array}{l}\text { SMDD irrigation ditch } 1 \\
\text { blw incised channel }\end{array}$ & 412104119125401 & 0.01 & $08 / 14 / 2019$ & 3-inch portable Parshall flume & Poor & NA \\
\hline SMDD incised channel & 412101119125801 & 1.63 & $08 / 13 / 2019$ & Acoustic doppler velocimeter & Poor & 0.066 \\
\hline \multirow[t]{2}{*}{ SMDD natural channel } & 412057119125501 & 2.18 & $08 / 14 / 2019$ & Acoustic doppler velocimeter & Poor & 0.071 \\
\hline & & 1.83 & $08 / 14 / 2019$ & Acoustic doppler velocimeter & Fair & 0.087 \\
\hline $\begin{array}{l}\text { SMDD natural channel abv } \\
\text { irrigation ditch } 2\end{array}$ & 412049119123401 & 1.93 & $08 / 15 / 2019$ & Acoustic doppler velocimeter & Poor & 0.072 \\
\hline SMDD irrigation ditch 2 & 412042119120001 & 0.02 & 08/15/2019 & 1-inch portable Parshall flume & Good & NA \\
\hline $\begin{array}{l}\text { SMDD natural channel } \\
\text { blw irrigation ditch } 2\end{array}$ & 412048119123201 & 2.01 & $08 / 15 / 2019$ & Acoustic doppler velocimeter & Fair & 0.139 \\
\hline $\begin{array}{l}\text { SMDD natural channel abv } \\
\text { irrigation ditch } 3 \text { and } 4\end{array}$ & 412036119120401 & 2.17 & 08/16/2019 & Acoustic doppler velocimeter & Fair & NA \\
\hline SMDD irrigation ditch 3 & 412036119115801 & 0.01 & $08 / 15 / 2019$ & 1-inch portable Parshall flume & Fair & NA \\
\hline SMDD irrigation ditch 4 & 412035119120201 & 0.04 & 08/15/2019 & Acoustic doppler velocimeter & Poor & NA \\
\hline
\end{tabular}

Because the stream channels are confined within nearly vertical walls, the additional streamflow would only increase the stream channel depth, not the width. Additionally, because the amount of additional streamflow is so small, the change in mean channel velocity is thought to be essentially zero. Therefore, the only variable changing is the mean depth $\left(D_{e}\right)$ :

$$
Q_{e}=D_{e} W_{m} V_{m}
$$

which can be rearranged to solve for mean depth as

$$
D_{e}=\frac{Q_{e}}{W_{m} V_{m}}
$$

\section{Topographic Data}

In August 13-15, 2019, Global Navigation Satellite System (GNSS) surveys were completed to determine locations of bridges and a culvert, as well as topographic points such as dry and flowing stream channel locations, streamflow measurements sites, and possible high-water marks. The GNSS surveys consisted of single-baseline Online Positioning User Service-Static (OPUS-S) surveys at one location for survey control, and single-base, real-time kinematic (RTK) GNSS surveys using the methods outlined in Rydlund and Densmore (2012). Owing to the distance to published benchmarks, OPUS-S surveys were completed on a temporary benchmark near the downstream end of the model area, to level 1 quality ( $0.18 \mathrm{ft}$ elevation uncertainty).
During the RTK surveys, points were collected at 1-second intervals for 3 minutes (180 epochs) at survey control, blunder checks, bridges, and culvert locations. Topographic points were collected at 1 -second intervals for 5 seconds (5 epochs). The topographic points include 14 locations within the flowing natural stream channel at the downstream end of the model reach, where the channel bottom was surveyed, and the water depth was measured to determine a water surface elevation for use in model calibration (fig. 6). Both OPUS-S and RTK GNSS surveys were completed using Leica GS14 GNSS receivers. All RTK points were of level 4 quality $(>0.32 \mathrm{ft}$ elevation uncertainty).

In April 2018, aerial light detection and ranging (lidar) data were acquired in the spring complex for the BLM by Quantum Spatial, Inc. The lidar data had a vertical accuracy of $0.12 \mathrm{ft}$ at the 95 -percent confidence level for non-vegetated areas (root mean square error [RMSE] of $0.06 \mathrm{ft}$ ) and of $0.57 \mathrm{ft}$ at a 95 -percent confidence level for the vegetated areas (RMSE of $0.29 \mathrm{ft}$ ). These values are within the accuracy of quality level one lidar data (U.S. Geological Survey, 2019c). To verify the suitability of combining the lidar data with the GNSS surveyed data, 265 topographic points were surveyed during the GNSS survey in both lightly and densely vegetated areas. The vertical accuracy at the 95-percent confidence level between the GNSS and nearest lidar-derived topographic points was acceptable at $0.19 \mathrm{ft}$ (RMSE of $0.16 \mathrm{ft}$ ). The filtered ground points from the lidar and GNSS topographic points were combined to create a 1 -ft triangulated irregular network (TIN) of the model area. Topographic data were released as part of a USGS data release (Morris, 2021). 


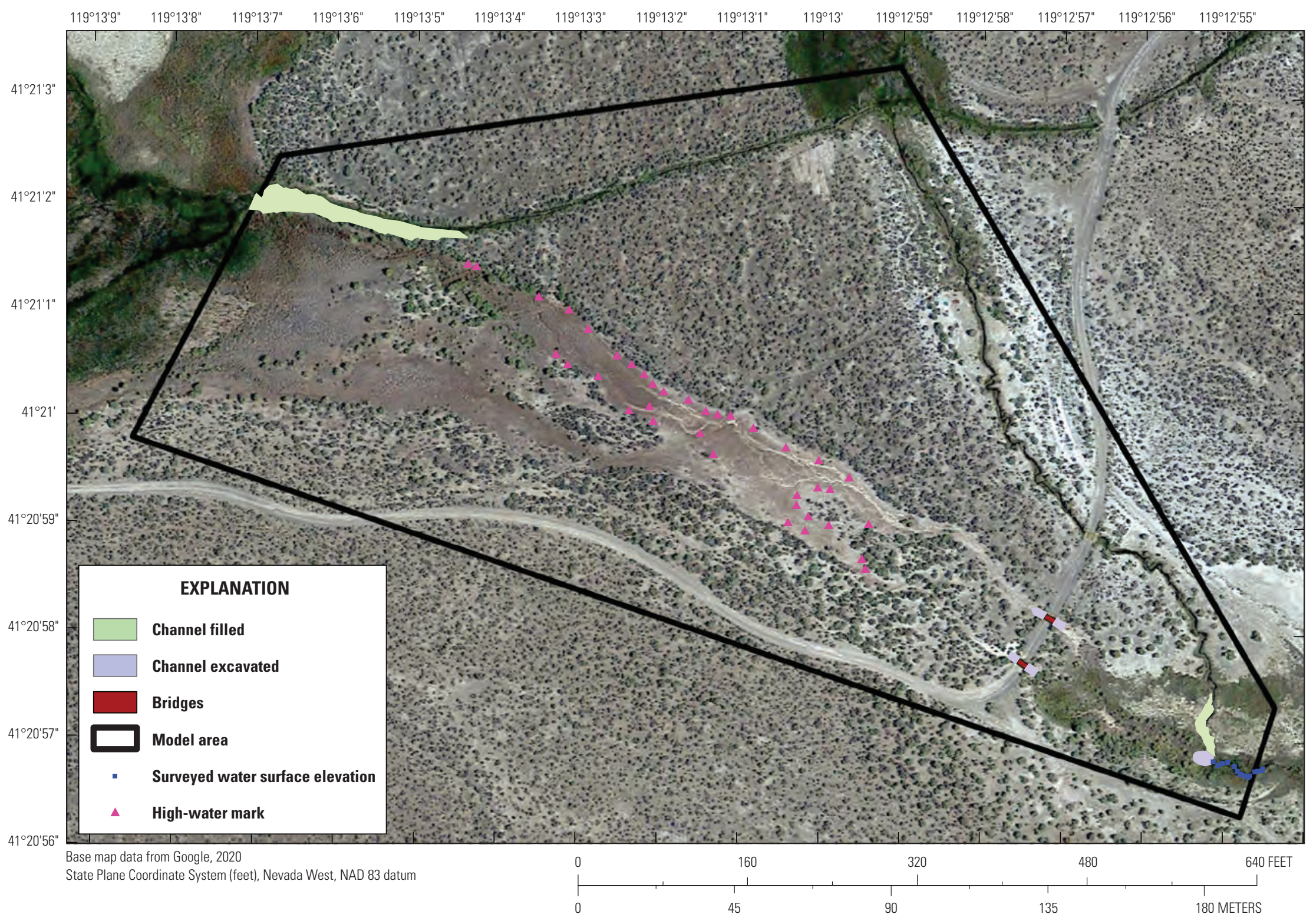

Figure 6. Model area, Soldier Meadows, Black Rock Desert-High Rock Canyon Emigrant Trails National Conservation Area, Nevada. 


\section{Evaluation of Streamflow Extent and Hydraulic Characteristics}

The spatial extent of streamflow and hydraulic characteristics of stream depth and velocity were estimated using a two-dimensional hydraulic model in Hydrologic Engineering Center's River Analysis System (HEC-RAS), version 5.0.7 (U.S. Army Corps of Engineers, 2016). The hydraulic model consisted of a restoration scenario in which (1) irrigation ditch 1 was filled in for a length of $200 \mathrm{ft}$ at its upstream end and (2) the incised channel was filled in for a length of about $60 \mathrm{ft}$ at its downstream end. The goal of the model scenario is to simulate the return of streamflow into the dewatered natural channel from the wetland. Streamflow areas detached from the main channel without surface water connections were removed from the final model results, although those locations could become naturally inundated with shallow groundwater if restoration were to occur and the groundwater table were to rise.

A steady streamflow of $1.9 \mathrm{ft} 3 / \mathrm{s}$ was used in the hydraulic model and computed by averaging all streamflows measurement made in August 2019 at SMDD incised channel, SMDD irrigation ditch 1 above the incised channel, and SMDD natural channel (table 1) because the variability in stream discharge is minimal and within measurement uncertainty.

\section{Model Geometry}

The primary data input in the model was the 1-ft TIN, and to simulate the proposed restoration scenario, several adjustments were made to the TIN. Near the upstream end of the model area, the elevations of the $200 \mathrm{ft}$ of irrigation ditch 1 were replaced with surrounding land surface elevations, to represent filling in of the ditch. The elevations of the $60 \mathrm{ft}$ of incised channel near the downstream end were similarly replaced with surrounding land surface elevations. The proposed restoration action calls for the entire length of the incised channel to be filled, but only the downstream end of the incised channel affects the model; therefore, only the downstream end of the incised channel was replaced with surrounding land surface elevations.

Currently (2019), the streamflow in the incised channel goes under the road at a cattle guard that has been placed on concrete footers, forming a small bridge over the channel. Two more cattle guard bridges are present on the road at the dewatered natural channel; however, both were filled with sediment. Future restoration efforts would remove sediment under the bridges to allow streamflow to continue downstream. Consequently, an estimated $0.1-2 \mathrm{ft}$ of elevation was subtracted from the land surface elevations to simulate this sediment removal and was extended about $10 \mathrm{ft}$ upstream and downstream of the bridges for grading to smooth the transition. Finally, at present, there is a large 1-2 ft elevation drop from the dewatered natural channel into the watered natural channel at the junction with the incised channel. This drop would act as a knickpoint, possibly leading to habitat fragmentation and new channel incision. A $20-\mathrm{ft}$ section of elevation was graded to smooth the transition from dewatered to watered natural channel. Because the streamflow was modeled to never reach the bottom of the bridge decks, the bridges were conceptualized as concrete box culverts with natural channel bottoms in the model. All the locations of topographic adjustments are shown in figure 6 .

The downstream boundary condition was set at the surveyed water surface of $4,444.08 \mathrm{ft}$ because the downstream end of the model area was not expected to change with restoration. The upstream boundary condition was set at the measured streamflow of $1.9 \mathrm{ft} 3 / \mathrm{s}$ and was held steady over the simulated period of 5 hours to ensure the streamflow fully equilibrated in the model.

\section{Roughness Coefficients}

In addition to the topography of the land surface, the water depth and velocity are also controlled by friction with vegetation and channel material. This roughness, defined by Manning's n-value, was computed at five of the streamflow measurement locations. The methods described in Jarrett and Petsch (1985) were used to compute the roughness coefficient by rearranging Manning's equation:

$$
n=\frac{1.486}{Q} A R^{2 / 3} S^{1 / 2}
$$

where

$$
\begin{array}{ll}
Q & \text { is the measured streamflow ( } \mathrm{ft} 3 / \mathrm{s}), \\
A & \text { is the channel area (square feet), } \\
R & \text { is the hydraulic radius (feet), and } \\
S & \text { is the water surface slope (unitless). }
\end{array}
$$

Estimates of roughness coefficient are presented in table 1 . The computed roughness coefficients ranged from 0.066 to 0.139 .

Measurement sites were in locations of well-defined channels and where vegetation was at a minimum; therefore, the computed roughness coefficients are less applicable to areas of shallow water depths and dense vegetation that occurs in the center and upper ends of the modeled area. Roughness coefficients at these locations were set to 0.25 based on field observations and estimated using similar sites with dense bulrush and cattails (Hall and Freeman, 1994; Soong and others, 2012). In the middle and lower sections of the modeled area, channels were narrower and more similar to measurement sites, and roughness coefficients were set to between 0.07 and 0.1 . Finally, although upland locations were not expected to be inundated, roughness coefficients of 0.2 were assigned to areas of very shallow depths in open sagebrush (Weltz and others, 1992). The specific response of vegetation production and resulting density to water being returned to the dewatered natural channel is unknown. The roughness coefficients for the currently dewatered natural channels are only estimates within a range of possible values. 


\section{Model Calibration}

Model calibration was accomplished by (1) developing a model geometry that represents the proposed restoration design and (2) iteratively adjusting computed roughness coefficients to minimize differences between simulated and measured water surface elevations and streamflow velocities. The model geometry included the following primary changes to the 1-ft TIN that represents the current (2019) land surface:

- Infilling of the first $200 \mathrm{ft}$ of irrigation ditch 1 and the last $60 \mathrm{ft}$ of the incised channel.

- An estimated 0.1-2 ft was subtracted from land-surface elevations to simulate sediment removal upstream and downstream of the bridges.

- A 20-ft section of land-surface elevation was graded (reduced) in the model to simulate a smooth transition from dewatered to watered natural channel at the current location of a knickpoint.

Roughness coefficients were iteratively adjusted during the calibration process within a range of computed values to provide an additional constraint on minimizing differences in simulated and measured water-surface elevations and streamflow velocity.

The dataset used for model calibration included fourteen water-surface elevation measurements and a mean streamflow velocity at downstream locations of the natural channel and model area (fig. 6). All water surface and velocity measurements are for August 2019, and the mean streamflow velocity represents two measurements at the SMDD natural channel location (table 2). Calibration datasets were limited to surface-water data for unaltered areas of the hydraulic model geometry; consequently, water-surface elevation and streamflow velocity measurements for irrigation ditch 1 and the incised channel (fig. 2; table 1) were not used for model calibration.

The calibrated model simulated surveyed surface water elevations by an average of $0.10 \mathrm{ft}$ too high (fig. 7), indicating roughness coefficients might be too large, whereas simulated mean velocity was 0.17 feet per second (ft/s) too large, indicating roughness coefficients might be too small. Examining the simulated versus surveyed water surface elevations, the largest differences were located near the center of the natural channel reach used for calibration, near a channel bend, where five simulated water surface elevations were on average $0.18 \mathrm{ft}$ too high (fig. 7). Moreover, there are numerous locations of undercut banks in the study area where the TIN may be incorrect. The undercut banks in this section of the natural channel may be the cause of the larger model calibration error in water surface elevations. Both upstream and downstream of this section of the natural channel, the difference between simulated and measured water surface elevations was only $0.01 \mathrm{ft}$ and $0.05 \mathrm{ft}$, respectively, indicating good calibration elsewhere in the natural channel.

In the upstream reaches of the dewatered natural channel (fig. 5), sections of dry, friable root masses and stunted wetland plants were found that may indicate high-water marks and a total of 37 of these points were surveyed. Results of the model calibration indicate that the final simulated water surface had a mean difference from the surveyed possible high-water marks of $-0.06 \mathrm{ft}$. Surveyed elevations of possible high-water marks were not used as a dataset for model calibration because of uncertainty on the magnitude of stream discharge for past flows and on whether the roots were submerged or not; however, the surveyed points may provide a general idea of past water surface elevations.

Table 2. Estimated streamflow and increase in channel depth of natural channel with irrigation ditches filled in.

[ft $3 / \mathrm{s}$, cubic foot per second; ft, foot; SMDD, Soldier Meadows Desert Dace; abv, above; blw, below]

\begin{tabular}{|c|c|c|c|c|}
\hline Site name & Site number & $\begin{array}{c}\text { Measured } \\
\text { streamflow } \\
\left(\mathrm{ft}^{3} / \mathrm{s}\right)\end{array}$ & $\begin{array}{l}\text { Estimated increase in } \\
\text { streamflow with "filled } \\
\text { in" irrigation ditches } \\
\left(\mathrm{ft}^{3} / \mathrm{s}\right)\end{array}$ & $\begin{array}{c}\text { Estimated increase in } \\
\text { streamflow depth with } \\
\text { "filled in" irrigation ditches } \\
\text { (ft) }\end{array}$ \\
\hline SMDD natural channel & 412057119125501 & 2.18 & 2.19 & 0.003 \\
\hline SMDD natural channel & 412057119125501 & 1.83 & 1.84 & 0.008 \\
\hline SMDD natural channel abv irrigation ditch 2 & 412049119123401 & 1.93 & 1.94 & 0.009 \\
\hline SMDD natural channel abv irrigation ditch 3 and 4 & 412036119120401 & 2.17 & 2.20 & 0.021 \\
\hline
\end{tabular}




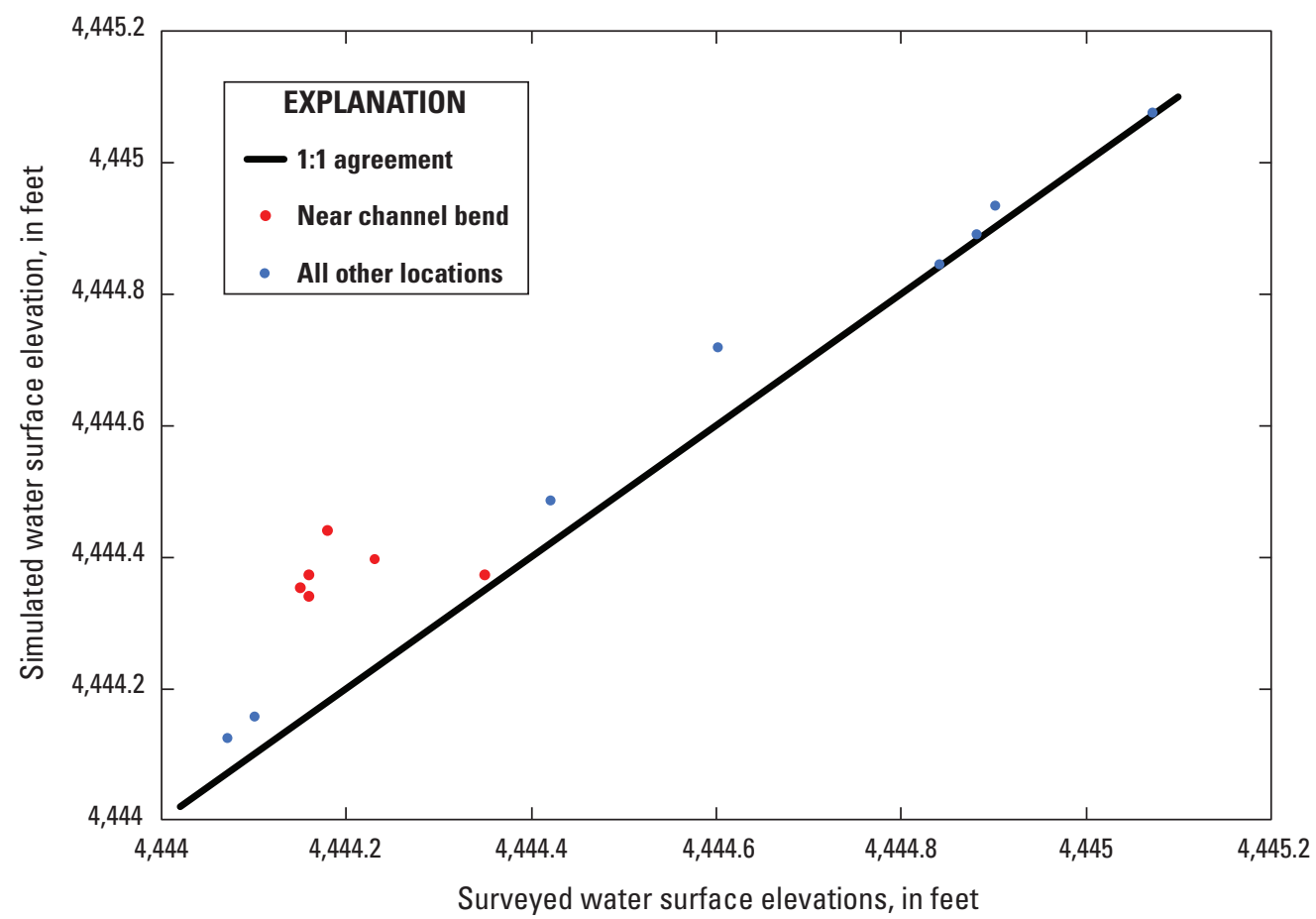

Figure 7. Simulated versus surveyed water surface elevations, Soldier Meadows, Black Rock Desert-High Rock Canyon Emigrant Trails National Conservation Area, Nevada.

\section{Results}

Except for irrigation ditch 1 above the incised channel, only very minor amounts of streamflow have been diverted from the natural channel to the irrigation ditches. Evaluation of streamflow measurements suggest that less than 1 percent of total streamflow occurs in irrigation ditches 1 (below the incised channel), 2, and 3, and less than 2 percent in irrigation ditch 4 . With the irrigation ditches filled in, estimated increases in the channel depth at measurement locations along the natural channel would be minimal with increases of $0.002-0.018 \mathrm{ft}$ (table 2).

Model results indicate that if irrigation ditch 1 above the incised channel were filled in, streamflow would return to the dewatered natural channel (fig. 8). Streamflow would continue southeast and spread into a wider section, where the streamflow depth would be about $0.15 \mathrm{ft}$ and streamflow velocities would be about $0.25 \mathrm{ft} / \mathrm{s}$ (figs. 9 and 10). Farther southeast, streamflow in the natural channel would split into two narrower channels, where the depth would be about $0.30 \mathrm{ft}$ and velocities would be about $1 \mathrm{ft} / \mathrm{s}$. The two narrow channels would go under the two bridges before rejoining, just upstream of the incised channel, where the depth would be about $0.20 \mathrm{ft}$ and velocities would be about $0.75 \mathrm{ft} / \mathrm{s}$. Past the incised channel near the downstream end of the model area, the vast majority of the streamflow would continue into the current natural channel, although a small amount is predicted to split from the natural channel to the north and flow into a wide, shallow area of about $0.10 \mathrm{ft}$ deep. Compared to the current conditions, simulated streamflow in the natural channel would be generally shallower, wider, and slower, but with locations of deeper and swifter streamflow. 


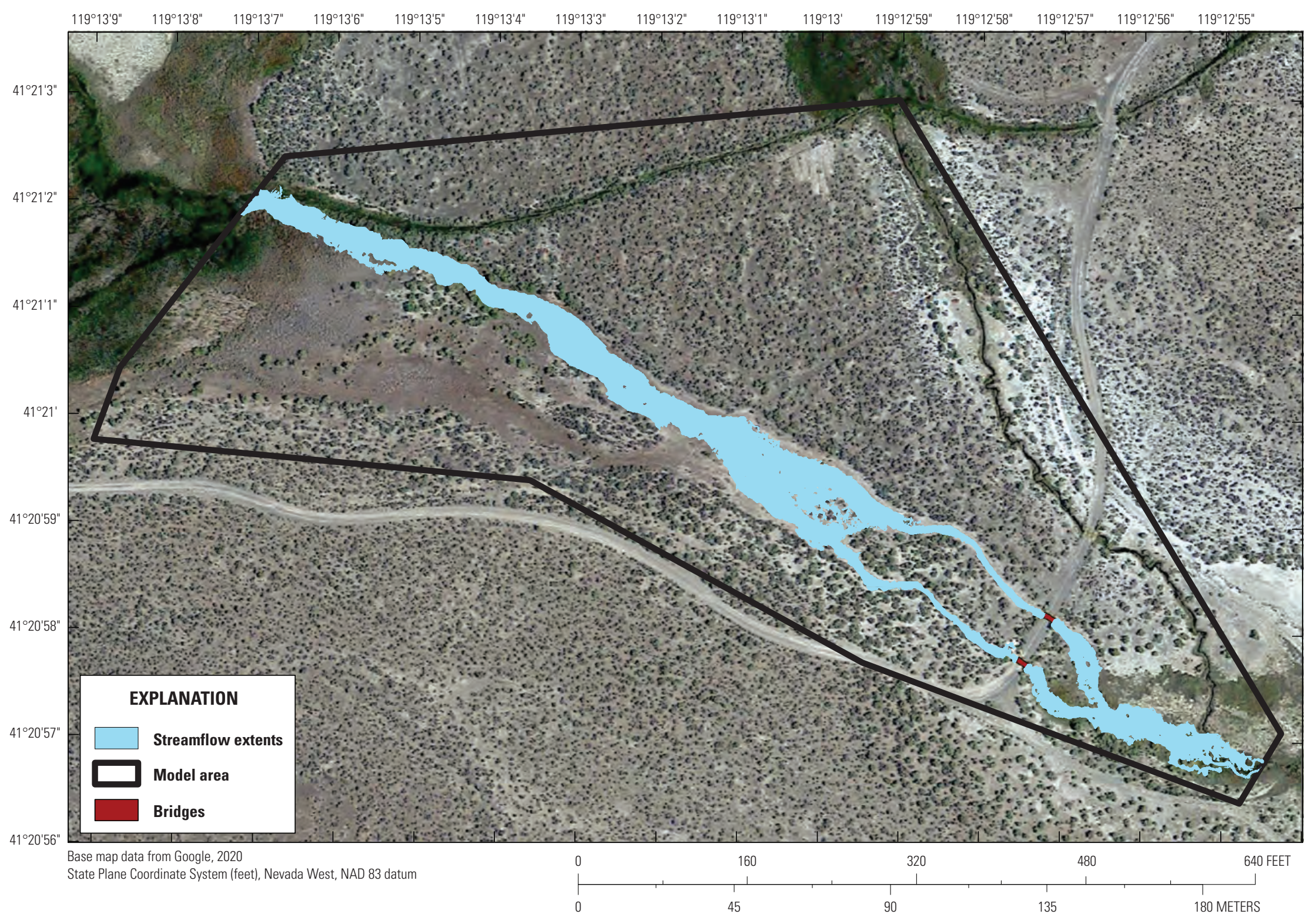

Figure 8. Simulated streamflow extents, Soldier Meadows, Black Rock Desert-High Rock Canyon Emigrant Trails National Conservation Area, Nevada. 


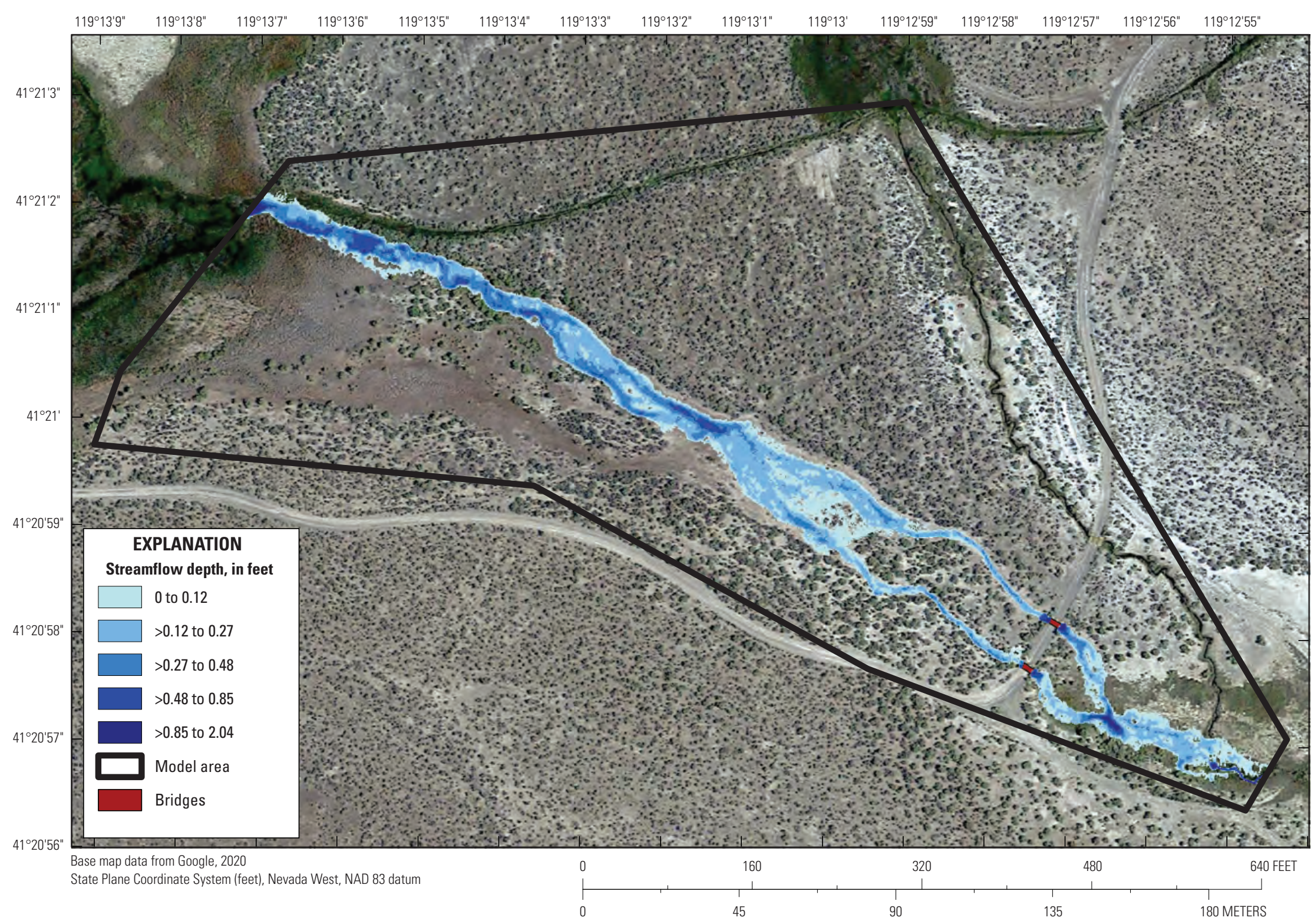

Figure 9. Simulated total streamflow channel depths, Soldier Meadows, Black Rock Desert-High Rock Canyon Emigrant Trails National Conservation Area, Nevada. 


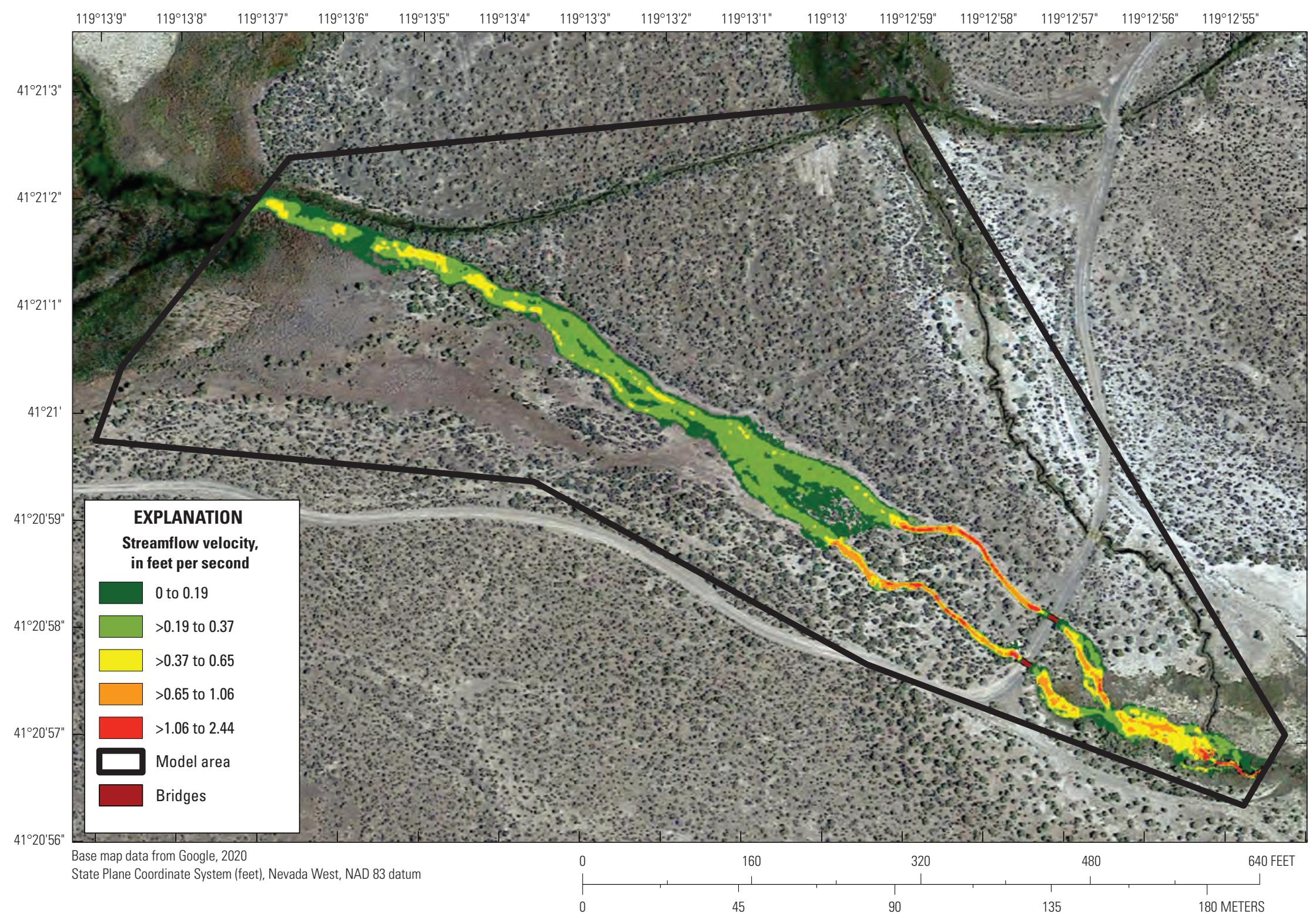

Figure 10. Simulated streamflow velocity, Soldier Meadows, Black Rock Desert-High Rock Canyon Emigrant Trails National Conservation Area, Nevada. 


\section{Discussion}

The hydraulic model predicts that filling in irrigation ditch 1 above the incised channel would allow water to return to the currently dewatered natural channel. The natural channel would be more heterogeneous, with areas ranging from wide, shallow, and slow to narrow, deep, and fast. A channel with varying flow hydraulic characteristics would be created in place of the current irrigation ditch and incised channel, likely resulting in greater habitat extents for the desert dace.

Irrigation ditches other than ditch 1 above the incised channel may have appeared to convey a large share of streamflow in 2019, but only minor amounts were being diverted from the natural channel. This is supported by historical evidence, such as Vinyard's (1996) observation that before irrigation dredging in 1989, most streamflow continued in the natural channel, and only when the irrigation ditches were cleaned of vegetation was significant streamflow diverted from the natural channel. The importance of vegetation conditions in the irrigation ditches and the variable nature of streamflow in the irrigation ditches over time is further illustrated by historical aerial photographs. Color infrared aerial photography from 1981 shows some vegetation in the dewatered natural channel but mostly ending upstream of the present-day bridges (U.S. Geological Survey, 1981; fig. 11). The natural channel downstream from the present-day bridges, as well as irrigation ditches 2-4, appear dry in 1981. Moreover, the extent of infrared colors in the imagery suggests that streamflow was diverted into irrigation ditch 1 to irrigate several fields with evidence of hay mowing. Based on the location of the darker wetland vegetation, black-and-white aerial photography from 1994 also appears to show that streamflow was diverted into irrigation ditch 1 to irrigate fields, which is also supported by Vinyard (1996). Comparing both images, the extent of vegetation in the natural channel in 1981 had expanded by 1994, but most of the streamflow in 1994 appears to have been diverted into irrigation ditch 2 (U.S. Geological Survey, 1994; fig. 12). Differences in the dark wetland vegetation from 1994 with green wetland vegetation from natural color aerial photography from the 2006 image indicate that vegetation growth in the natural channel continued to increase during this period. By 2006, vegetation and streamflow conditions were similar to present day conditions with the exception of the appearance of additional streamflow in irrigation ditch 1 below the incised channel (U.S. Geological Survey, 2006; fig. 13). The time sequence of aerial photography suggests that if irrigation ditches were cleaned of vegetation in the future, a greater portion of streamflow could be diverted from the natural channel than current (2019) diversions.

\section{Uncertainties and Limitations}

The results of the study have several limitations and uncertainties. Calibration data were limited to surface water elevations and streamflow velocity for downstream natural channel reaches that would remain unaltered for the proposed restoration design. The specific response of vegetation production and resulting density to water being returned to the natural channel also is unknown for the hydraulic model. Elsewhere in the spring complex, vegetation grows densely in locations with water, but the density of the vegetation is variable. If vegetation were to regrow more densely than estimated in the model, the roughness coefficients would increase and the conveyance would decrease, resulting in larger surface water depths, a larger spatial extent of streamflow, and lower streamflow velocities. Conversely, if vegetation were to regrow less densely than estimated in the model, water depths would be smaller, the spatial extent of streamflow smaller, and the velocities higher. Additionally, vegetation regrowth would occur over time, so water depths and spatial extent of water would increase over the regrowth period.

Several sections of the model used estimated channel modifications (removal and addition of channel material). The actual change in the channel will likely be different than specified in the model and could result in differences in simulated surface water elevation, velocity, and spatial extent.

Model simulations assume that streamflow is steady and does not vary seasonally. This assumption is supported by a 1.5-year continuous discharge record from nearby South Antelope Spring in the Soldier Meadows spring complex (U.S. Geological Survey, 2019a). However, some seasonal variation may occur to the steady discharge assumption used in the model. For example, streamflow measurements at SMDD Natural Channel made on January 2020 revealed a 22-percent increase in streamflow from the August 2019 measurements, whereas in April 2020, streamflow was only increased about 5 percent above the August 2019 measurements. January and April are typically periods of low evapotranspiration, therefore the additional streamflow measured in January compared to April is thought to be related to recent snowmelt or rainfall. The January streamflow measurements suggest that snowmelt and or rainfall during these months can increase streamflow and represent a seasonal maximum streamflow. Streamflow measurements used in this study to determine an average steady discharge of $1.9 \mathrm{ft} 3 / \mathrm{s}$ were made in August, the driest month of the year and at near maximum evapotranspiration conditions (National Oceanic and Atmospheric Administration, 2020), and are considered a seasonal minimum streamflow. Therefore, the simulation represents a seasonal minimum of surface water extent, streamflow channel depth, and streamflow velocity. 


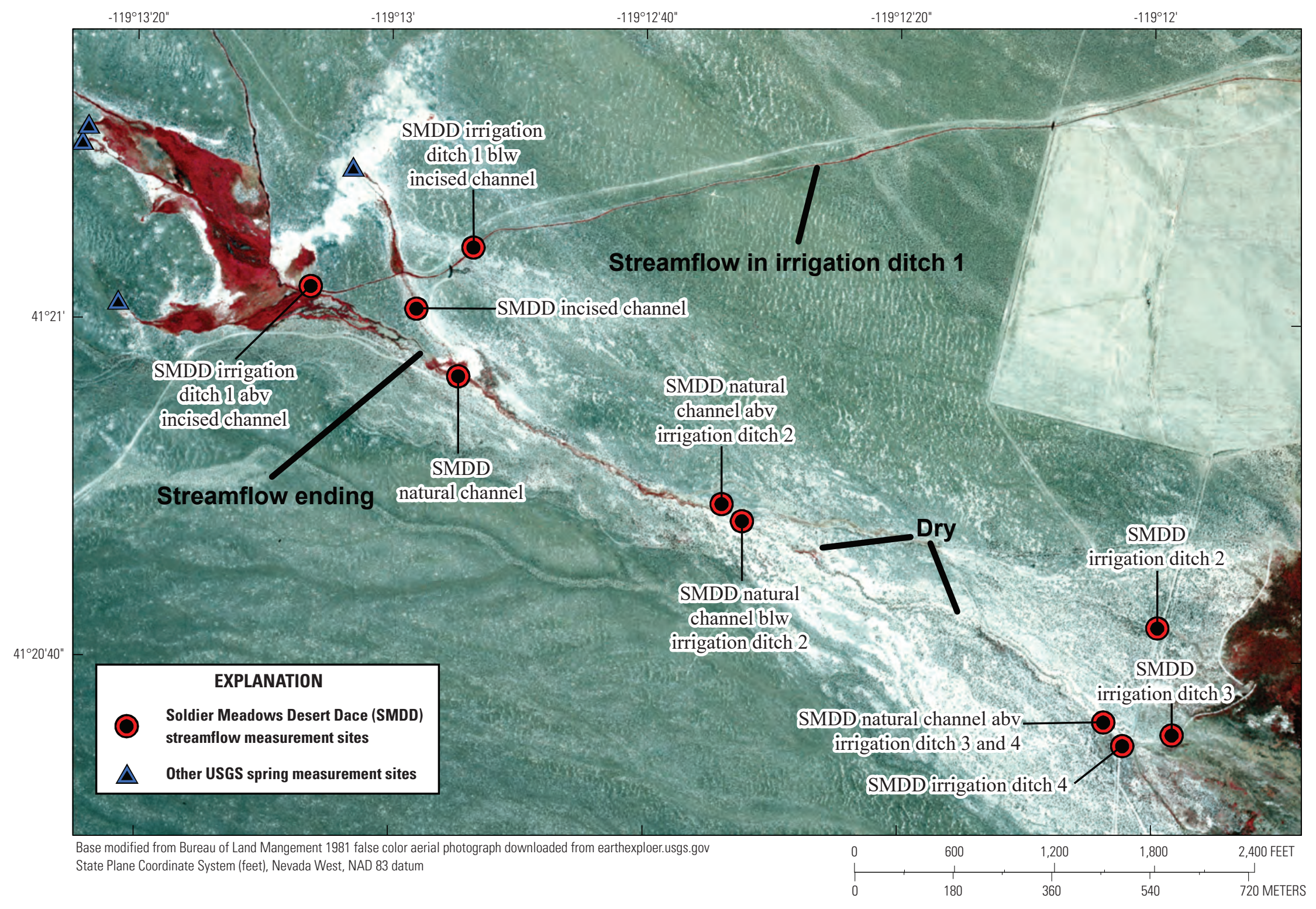

Figure 11. Color infrared aerial photograph of study area in 1981, Soldier Meadows, Black Rock Desert-High Rock Canyon Emigrant Trails National Conservation Area, Nevada. 


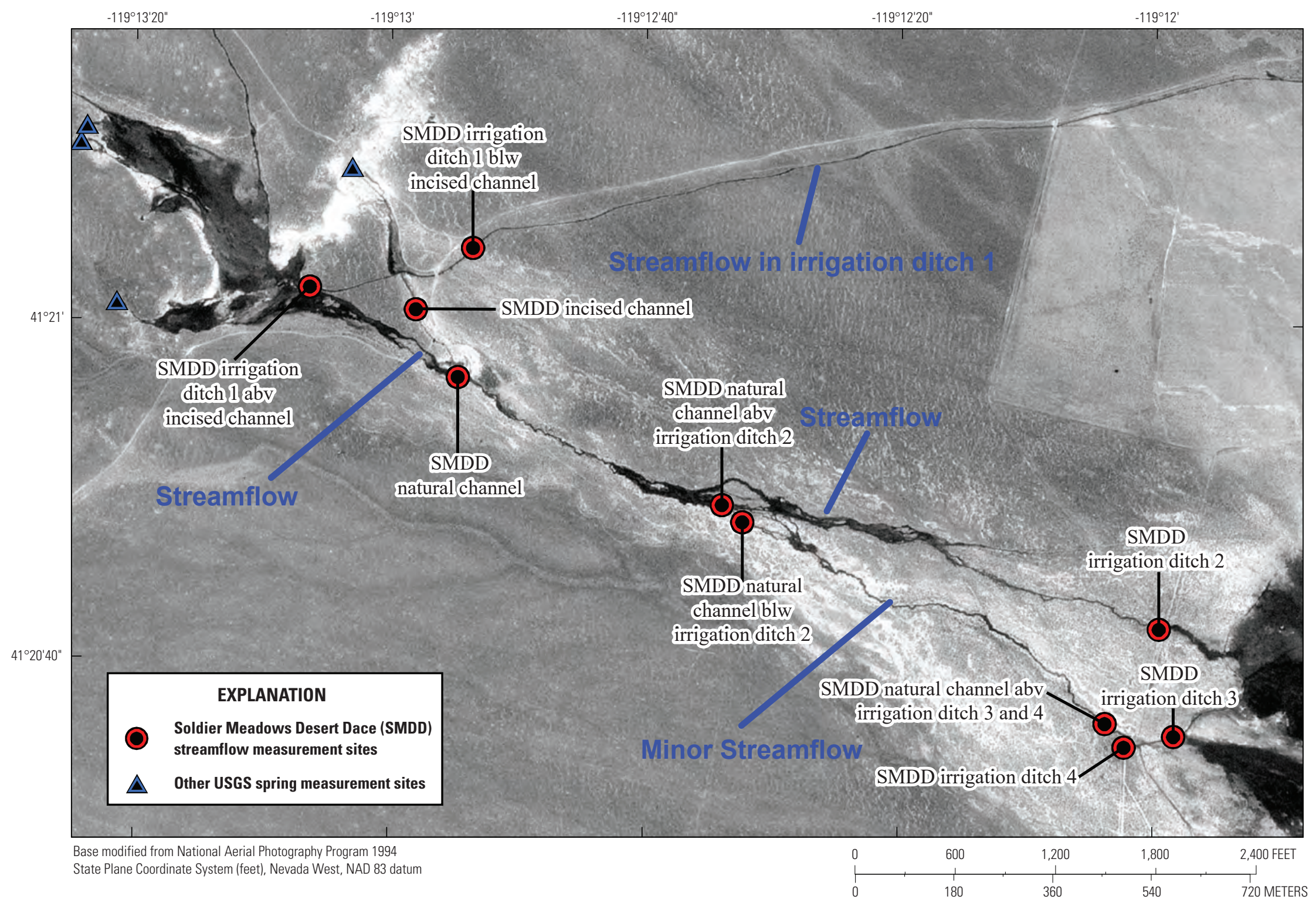

Figure 12. Aerial photograph of study area in 1994, Soldier Meadows, Black Rock Desert-High Rock Canyon Emigrant Trails National Conservation Area, Nevada. 


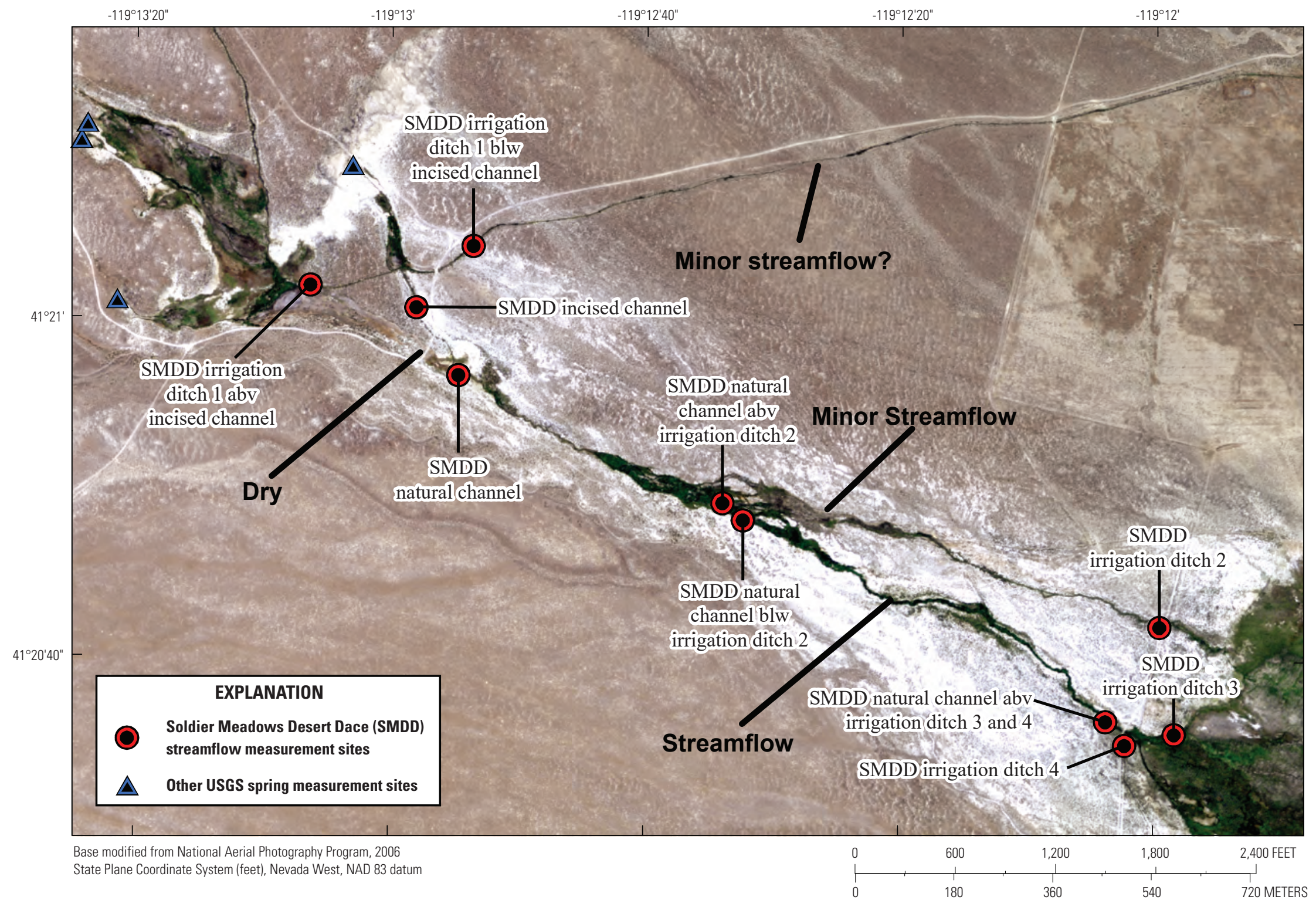

Figure 13. Aerial photograph of study area in 2006, Soldier Meadows, Black Rock Desert-High Rock Canyon Emigrant Trails National Conservation Area, Nevada. 
Additional streamflow measurements over time would improve understanding of variations in streamflow and thus the variability in restored channel conditions and desert dace habitats. Finally, since streamflow is relatively small and most channels are narrow, measurements are generally considered poor. Small variations of measured streamflow during this study probably reflect uncertainty in measurements rather than actual changes in streamflow.

\section{Summary and Conclusion}

Irrigation ditches in the Soldier Meadows spring complex have altered the hydrology as well as the habitat of the endemic, threated desert dace fish species. Irrigation ditches divert water from natural channels, resulting in lower quality habitat. Irrigation ditch condition is important because over time irrigation ditches can become choked with vegetation, thereby reducing the amount of water they divert from natural channels. With the exception of irrigation ditch 1 above the incised channel, streamflow measurements from 2019 showed that only very minor streamflows were diverted from the natural channel; consequently, filling in those irrigation ditches likely would have minimal effects on the surface water depths and extents of the rewetted natural channel. Hydraulic modeling found that filling in irrigation ditch 1 above the incised channel would return streamflow to the currently dewatered natural channel and would likely increase surface water depths and extent beyond current (2019) conditions. The result would be a more heterogenous stream channel condition with areas of wide, slow, and deeper flow to narrow, fast, and shallow.

\section{References Cited}

Bauman, B., 2019, Desert dace relative abundance and monitoring update 2019: Winnemucca, Nev., Nevada Department of Wildlife, $19 \mathrm{p}$.

Hall, B.R., and Freeman, G.E., 1994, Study of hydraulic roughness in wetland vegetation takes new look at Manning's n: The Wetlands Research Program Bulletin, v. 4 , no. 1 , p. 1-4.

Hubbs, C.L., and Miller, R.R., 1948, Two new relict genera of cyprinid fishes from Nevada: University of Michigan Museum of Zoology Occasional Papers no. 507, p. 1-30, accessed January 28, 2020, at http://hdl.handle.net/2027.42/56945.

Jarrett, R.D., and Petsch, H.E., 1985, Computer program NCALC user's manual; verification of Manning's roughness coefficient in channels: U.S. Geological Survey Water-Resources Investigations Report 85-4317, 27 p., accessed October 3, 2019, at https://doi.org/10.3133/wri854317.

Morris, C.M., 2021, Geospatial data and surface-water model archive for evaluation of streamflow extent and hydraulic characteristics of a restored channel at Soldier Meadows, Black Rock Desert-High Rock Canyon Emigrant Trails National Conservation Area, Nevada: U.S. Geological Survey data release, https://doi.org/10.5066/P9O0GII7.

National Oceanic and Atmospheric Administration, 2020, 1981-2010 normal for station GERLACH, NV US USC00263090: National Environmental Satellite, Data, and Information Service, accessed May 4, 2020, at https://www.ncdc.noaa.gov/cdo-web/datasets/NORMAL_ MLY/stations/GHCND:USC00263090/detail. 
Nyquist, D., 1963, The ecology of Eremichthys acros, an endemic thermal species of cyprinid fish from northwestern, Nevada: Reno, University of Nevada, Master's Thesis, $202 \mathrm{p}$.

Patten, D.T., Rouse, L., and Stromberg, J.C., 2008, Isolated spring wetlands in the Great Basin and Mojave deserts, USA-Potential response of vegetation to groundwater withdrawal: Environmental Management, v. 41, no. 3, p. 398-413, accessed November 14, 2019, at https://doi.org/10.1007/s00267-007-9035-9.

Rissler, P.H., and Scoppettone, G.G., 2004, Distribution of desert dace in relation to other fishes and water temperature in the Mud Meadow / Soldier Meadow Basin: Reno, Nev., U.S. Geological Survey, Western Fisheries Research Center, $32 \mathrm{p}$.

Rydlund, P.H., Jr., and Densmore, B.K., 2012, Methods of practice and guidelines for using survey-grade global navigation satellite systems (GNSS) to establish vertical datum in the United States Geological Survey: U.S. Geological Survey Techniques and Methods Report, book 11, chap. D1, 120 p. with appendixes, accessed February 12, 2016, at https://pubs.er.usgs.gov/publication/tm11D1.

Soong, D.T., Prater, C.D., Halfar, T.M., and Wobig, L.A., 2012, Manning's roughness coefficient for Illinois streams: U.S. Geological Survey Data Series 668, 14 p., https://doi.org/10.3133/ds668.

Turnipseed, D.P., and Sauer, V.B., 2010, Discharge measurements at gaging stations: U.S. Geological Survey Techniques and Methods book 3, chap. A8, 87 p., https://pubs.usgs.gov/tm/tm3-a8/.

U.S. Army Corps of Engineers, Hydrologic Engineering Center, 2016, HEC-RAS river analysis system, hydraulic reference manual, version 5.0: U.S. Army Corps of Engineers, variously paged, available at https://www.hec.usace.army.mil/software/hec-ras/ documentation.aspx.

U.S. Fish and Wildlife Service, 1997, Recovery plan for the rare species of Soldier Meadows: U.S. Fish and Wildlife Service, 49 p., accessed October 21, 2019, at https://ecos.fws.gov/docs/recovery_plan/970527.pdf.

U.S. Geological Survey, 1981, U.S. Geological Survey Earth Resources Observation and Science Center single frame aerial photography, AR4N81A16015086: U.S. Geological Survey EarthExplorer web page, accessed October 21, 2019, at https://doi.org/10.5066/F7610XKM.
U.S. Geological Survey, 1994, U.S. Geological Survey Earth Resources Observation and Science Center digital orthophotoquadrangle, DI00000001040670: U.S. Geological Survey EarthExplorer web page, accessed October 21, 2019, at https://doi.org/10.5066/F7610XKM.

U.S. Geological Survey, 2006, U.S. Geological Survey Earth Resources Observation and Science Center National Agricultural Imagery Program, N_4111947 NW_11_1_20060729: U.S. Geological Survey EarthExplorer web page, accessed October 21, 2019, at https://doi.org/10.5066/F7610XKM.

U.S. Geological Survey, 2019a, USGS 412537119094001026 N41 E25 32BABB1 S ANTELOPE SPG, in USGS water data for the Nation: U.S. Geological Survey National Water Information System database, accessed December 19, 2019, at https://doi.org/10.5066/F7P55KJN. [Site information directly accessible at https://waterdata.usgs.gov/nwis/ inventory/?site_no $=412537119094001$.]

U.S. Geological Survey, 2019b, USGS water data for the Nation: U.S. Geological Survey National Water Information System database, accessed December 19, 2019, at https://doi.org/10.5066/F7P55KJN.

U.S. Geological Survey, 2019c, Lidar base specification (ver. 2.1, February 2018): U.S. Geological National Geospatial Program Standards and Specifications web page, accessed December 19, 2019, at https://www.usgs.gov/corescience-systems/ngp/ss/lidar-base-specification-v-21-tablecontents.

Vinyard, G.L., 1988, Population status survey of the Soldier Meadows desert dace (Eremichthys across): Reno, Nev., U.S. Fish and Wildlife Service, Project Completion Report, Contract Number 14332-87-00178, 30 p.

Vinyard, G.L., 1996, Distribution of a thermal endemic minnow, the desert dace (Eremichthys acros), and observations of impacts of water diversion on its population: The Great Basin Naturalist, v. 56, no. 4, p. 360-368, accessed April 3, 2019, at https://scholarsarchive.byu.edu/gbn/vol56/iss4/10.

Weltz, M.A., Arslan, A.B., and Lane, L.J., 1992, Hydraulic roughness coefficients for native rangelands: Journal of Irrigation and Drainage Engineering, v. 118, no. 5, p. 776-790, accessed December 3, 2019, at https://doi.org/ 10.1061/(ASCE)0733-9437(1992)118:5(776). 
For more information concerning the research in this report, contact the

Nevada Water Science Center

U.S. Geological Survey

2730 N. Deer Run Road

Carson City, Nevada 95819

https://www.usgs.gov/centers/nv-water

Publishing support provided by the U.S. Geological Survey

Science Publishing Network, Sacramento Publishing Service Center 
